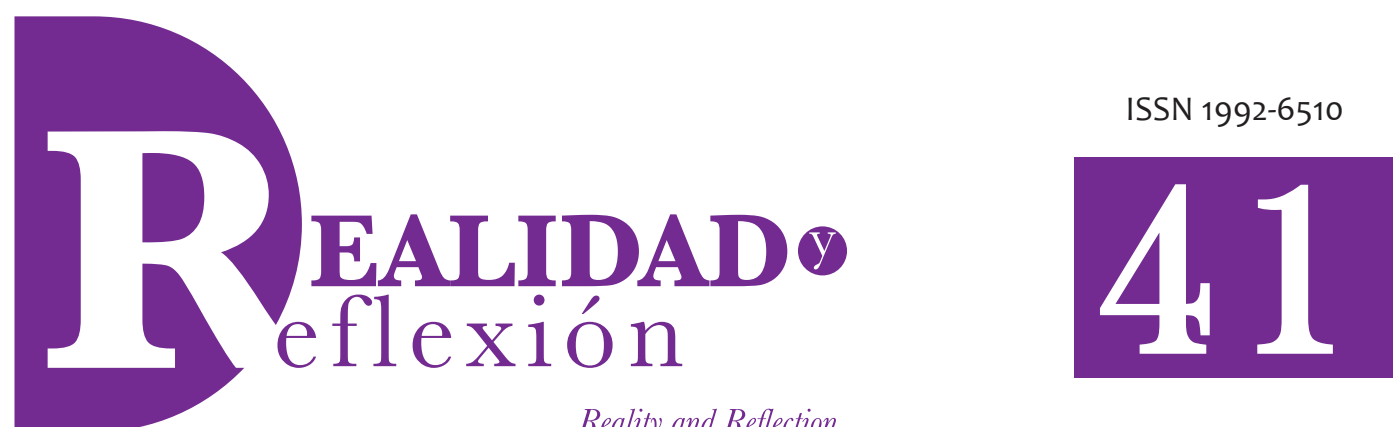

Reality and Reflection

año 15, No 41, San Salvador, El Salvador, Centroamérica Revista Semestral Enero-Junio 2015

YeAR 15, N41, SAN Salvador, El Salvador, CENTRAl America Semestral Journal January-June 2015

\title{
Regulación jurídico-penal de los delitos sexuales en El Salvador. Análisis desde una perspectiva de género
}

\author{
Legal regulation of sexual crimes in El Salvador. \\ Analysis from a gender perspective
}

\author{
Hazel Jasmín Bolaños Vásquez \\ Investigadora Asociada de la Universidad Francisco Gavidia. \\ Doctora en Derechos Humanos y Derecho Penal por la Universidad de Zaragoza. \\ hazelbolanosv@gmail.com
}

\section{RESUMEN}

El artículo hace un análisis de los delitos que protegen el bien jurídico libertad sexual en la legislación salvadoreña, centrándose principalmente en estudiar si los distintos tipos penales que sancionan la vulneración a este bien jurídico lo hacen desde una perspectiva de igualdad de género. Tras el análisis de los distintos tipos penales se apuntaron aquellos aspectos que evidencian una falta de sistematización entre los distintos artículos. Así, se señala que aspectos tales como la edad de consentimiento sexual de las personas menores de edad y la obligación de indemnizar a las víctimas de delitos contra la libertad sexual no han sido regulados de forma equivalente.

Asimismo, se observa que en la actual protección del bien jurídico en estudio persisten estereotipos de género, que llevan por un lado a que ciertas conductas protejan exclusivamente a las personas menores de edad o a las mujeres, y por otro lado, que se gradué la protección del bien jurídico con base en la sanción del acceso carnal como infracción más grave, sin tomar en cuenta aspectos relevantes tales como el grado de afectación y vulneración de la integridad física, sexual y emocional del sujeto pasivo. LIBERTAD SEXUAL, DELITOS SEXUALES, VIOLENCIA SEXUAL, IGUALDAD DE GÉNERO. 


\section{ABSTRACT}

The article analyzes the offenses that protect the legal right to sexual freedom in Salvadoran law, focusing primarily on studying if the different types of crimes that punish the infringement of this legal right, do it from a gender equality perspective. After analyzing the various offenses, the author points that there is a lack of systematization between the different offenses. Thus, aspects such the age of sexual consent for minors and the obligation to compensate the victims of crimes against sexual freedom are not regulated in a equal manner.

Further, the author notes that in the current protection of the legal right in study persist gender stereotypes that lead on one side, that certain behaviors solely protect minors or women, and, on the other hand, the protection of the legal right is graduated on the basis of the sanction of sexual intercourse as the most serious offense, regardless of relevant aspects such as the degree of physical, sexual and emotional damage of the passive subject of the crime. SEXUAL FREEDOM, SEXUAL CRIMES, SEXUAL VIOLENCE, GENDER EQUALITY.

\section{Introducción}

La violencia sexual es definida por la Organización Mundial de la Salud como "todo acto sexual, la tentativa de consumar un acto sexual, los comentarios o insinuaciones sexuales no deseados, o las acciones para comercializar o utilizar de cualquier otro modo la sexualidad de una persona mediante coacción por otra persona, independientemente de la relación de esta con la víctima, en cualquier ámbito, incluidos el hogar y el lugar de trabajo". La violencia sexual constituye, asimismo, una violación de los derechos humanos y libertades fundamentales, especialmente de las mujeres, que son las principales víctimas de este tipo de violencia. ${ }^{2}$

Por lo tanto, la violencia sexual tiene un impacto en la vida de las mujeres, adolescentes y niñas que la sufren, tanto como hecho potencial como consumado. Las experiencias de violencia sexual y el miedo a la misma, limitan la libertad y la autonomía de las mujeres, su derecho a la movilidad, educación, recreación, organización colectiva y participación política. Las distintas formas de violencia sexual que enfrentan las mujeres en los diferentes espacios públicos, privados y semiprivados en que se desenvuelven, $y$ en todas las etapas del ciclo vital forman parte de un continuum de discriminación y exclusión social. 3

Asimismo, investigaciones y estadísticas han demostrado que la violencia sexual constituye uno de los problemas de derechos humanos más extendidos que ocurre en América Latina y el Caribe. Así, según los datos de la investigación realizada en la región por Contreras, Bott, Guedes, \& Dartnall en el 2010,4 la proporción de mujeres que declaran haber sido sometidas alguna vez a relaciones sexuales forzadas por una pareja íntima es del 5 al 47 por ciento. Este es un indicador crítico de marginación, desigualdad, exclusión y discriminación de género contra las mujeres que tiene implicaciones en la autonomía, la auto-determinación, la salud individual y colectiva, y el ejercicio de la ciudadanía. De igual forma, la violencia sexual se encuentra asociada a otras problemáticas igualmente preocupantes tales como la mortalidad materna, abortos inseguros, los embarazos no deseados entre las adolescentes y adultas, las infecciones de transmisión sexual, incluyendo el VIH, entre otros. ${ }^{5}$ 
Igualmente crítica es la situación que enfrentan los niños y niñas víctimas de explotación sexual comercial, quienes además de toda la problemática que ya implica el ser víctimas de violencia sexual, también son muy propensos a padecer problemas de salud causados por una infección de transmisión sexual y problemas de salud mental tales como agitación y ansiedad, sentimientos de culpa, manifestaciones claras de tristeza, pérdida de apetito, perturbación del sueño, entre otros. ${ }^{6}$

Conscientes de esta situación, todos los países de Latinoamérica han ratificado la Convención sobre la Eliminación de todas las Formas de Discriminación contra la Mujer (CEDAW) y la mayoría han ratificado la Convención Interamericana para Prevenir, Sancionar y Erradicar la Violencia contra la Mujer (Convención de Belém do Pará). ${ }^{7}$ Asimismo, en casi todos los países de la región se han aprobado reformas legales para proteger a las víctimas, castigar a los perpetradores y penalizar las diferentes formas de violencia, incluyendo la sexual. ${ }^{8}$ Algunas leyes incluso incorporan tipos penales contra la violencia obstétrica, la violencia contra la libertad reproductiva y la violencia en los medios de comunicación. ${ }^{9}$

No obstante la legislación existente, los sistemas de justicia nacionales presentan severas limitaciones en la implementación de medidas para proteger a las víctimas y castigar a los perpetradores de la violencia sexual, y el patrón de impunidad continúa permeando la región. ${ }^{10}$ En este sentido, la Comisión Interamericana de Derechos Humanos señala que las víctimas/ sobrevivientes de violencia sexual en la región americana enfrentan limitaciones de acceso a la justicia entre las que se encuentran los estereotipos de género, que se expresan en prejuicios de género en los funcionarios del sistema de justicia que colocan en desventaja a las mujeres. Estos estereotipos contribuyen a la impunidad de los delitos de violencia sexual y perpetúan la aceptación social de la violencia contra las mujeres, el sentimiento y la sensación de inseguridad en las mujeres, y la persistente desconfianza de estas en el sistema de administración de justicia. ${ }^{11}$

Estos estereotipos también se reflejan en la sociedad salvadoreña. En efecto, socialmente se ha percibido la "disciplina sobre los cuerpos" como factor de control social de uso exclusivo del grupo dominante masculino. Tal como lo afirma: "Dicha exclusividad pasa con facilidad por la vía simbólica a la asociación del placer con las estrategias de sometimiento social por medio de una interacción violenta" ${ }^{12}$, lo que ha conllevado a la naturalización de la violencia sexual entre los géneros y las generaciones como técnica fundamental de control.

Esta naturalización se vio reflejada en la legislación salvadoreña por muchos años. Así, si bien desde los primeros códigos penales se reconocía a la violencia sexual como una conducta delictiva, ésta se consideraba una ofensa contra la honra y el honor y, por lo tanto, lo que se buscaba era proteger las buenas costumbres y la moral, más que la libertad sexual de la víctima. ${ }^{13}$ Por ejemplo, el Código Penal de 1826 sancionaba únicamente la violación en mujer casada, desposada u "otra persona que no sea mujer pública conocida como tal” (Arts. 703 y 704 CP de 1826). ${ }^{14}$ En el Código Penal de 1904 se regulaba a los delitos sexuales en el 
capítulo II, denominado "Violación y Abusos Deshonestos", y en virtud del cual el delito de violación sexual podía ser cometido exclusivamente en una niña o mujer (Art. 392 CP de 1904) $)^{15}$, consumándose el delito con la penetración del órgano sexual masculino en el órgano sexual femenino y, por lo tanto, el bien protegido era la sexualidad genital de la mujer. ${ }^{16}$

Mientras que el Código Penal de 1974 se hace una diferencia entre la violación propia e impropia, siendo la diferencia entre estas el "vaso" en que fuere realizado el acceso carnal. Así, se consideraba violación propia a aquella violación realizada en el genital de la mujer, mientras que la impropia consistía en el acceso carnal realizado por varón en otro varón o con mujer por "vaso indebido" (Art. 194 CP de 1974). ${ }^{17}$ No obstante que — tal como veremos Infraen el actual Código Penal se han derogado las distinciones sobre la "honestidad" u "honra" del sujeto pasivo, aún persisten en el imaginario social un "sesgo moralista" que invisibiliza a las víctimas. ${ }^{18}$

En este sentido, las estadísticas sobre violencia sexual en El Salvador hacen eco de estas afirmaciones. Así, la Encuesta

\footnotetext{
14 Dichos Artículos disponían: Art. 703. El que abuse deshonestamente de una mujer casada o desposada haciéndole creer sinceramente, por medio de algún engaño o ficción bastante para ello que es su marido o esposo legítimo, sufrirá la pena de cuatro a ocho años de obras públicas, y después la de destierro del pueblo, y veinte leguas en contorno, por el tiempo que viva en él, su marido o esposo.

Art. 704. El que abuse del mismo modo de mujer casada contra la voluntad de esta, privándola previamente para ello del uso de su razón con licores fuertes u otras confecciones o medios que produzcan el mismo efecto, o aprovechándose de la ocasión en que ella esté sin sentido por un accidente físico, u otra enfermedad u ocurrencia, sufrirá igual pena que la suscrita en el Artículo precedente, no pudiendo ser acusada sino por la mujer o su marido. El que cometa este propio delito contra cualquiera otra persona que no sea mujer pública conocida como tal, sufrirá una reclusión de cuatro a ocho años, con igual destierro, mientras viva el ofendido.
}

Nacional de Salud Familiar (FESAL), de 2008, mostró que el 13 por ciento de las mujeres de 15 a 49 años de edad reportó que en el transcurso de la vida experimentó alguna forma de violencia sexual, el 10 por ciento alguna situación de abuso sexual, entendido este como el forzamiento u obligación a desvestirse, tocar las partes íntimas o hacer otros actos sexuales sin llegar a la penetración; y el 8 por ciento reportó alguna situación de sexo forzado, también llamado "violación", definido como el forzamiento u obligación a tener relaciones sexuales con penetración. Asimismo, el 4 por ciento de las mujeres reportó que fue víctima de ambos tipos de violencia sexual. De igual forma, la citada encuesta, al comparar entre las mujeres que algunas vez han estado casadas o acompañadas revela que las mujeres víctimas de violencia superan en más del doble a las que reportaron no haberla sufrido (Figura 1).

Estas estadísticas se pueden ver reflejadas en los datos que registró la Policía Nacional Civil (PNC) durante el 2013, año en el que se recibieron 1,820 denuncias por delitos de violencia sexual entre los que se encontraban los delitos de violación, violación en menor e incapaz, agresión sexual en menor e incapaz y otras agresiones sexuales. ${ }^{19}$

\footnotetext{
15 Art.- 392.- La Violación de una mujer será castigada con nueve años de presidio.

1. ${ }^{\circ}$ Cuando se usare la fuerza o intimidación;

$2 .^{\circ}$ Cuando la mujer se hallare privada de razón o sentido por cualquier causa;

$3 .^{\circ}$ Cuando fuere menor de doce años cumplidos, aunque no concurriere ninguna de las circunstancias expresadas en los números anteriores.

17 Art. 194. Violación Impropia. Es Violación impropia, el acceso carnal realizado por varón en otro varón o con mujer por vaso indebido. En estos casos la pena será de cuatro a ocho años de prisión. Cuando la víctima fuere menor de doce años la pena se agravará hasta una tercera parte del máximo aunque aquella diere su consentimiento.
} 


\section{Figura 1}

\section{Comparación de las características de las mujeres sin y con violencia física o sexual durante la vida: Mujeres de 15 a 49 años alguna vez casadas o acompañadas.}

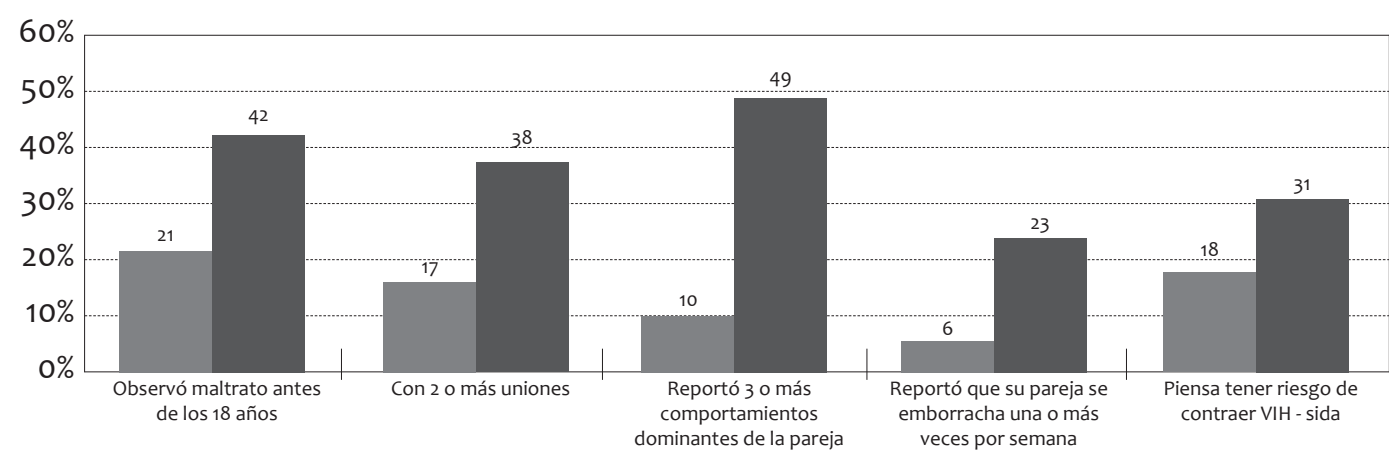

Sin violencia física o sexual

Con violencia física o sexual

Fuente: ADS (2009), p. 244

Asimismo, en la encuesta FESAL, se indagó sobre la edad que tenían las mujeres que fueron víctimas del abuso sexual o sexo forzado la primera vez que les sucedió, indicando los datos, en general, que la niñez y la adolescencia son períodos de alto riesgo para ambos tipos de violencia sexual.

Así, la mitad de las mujeres víctimas de abuso sexual reportó que su primera experiencia ocurrió a una edad menor de los 15 años, mientras que el 26 por ciento de los 15 a los 19 años de edad. Mientras que la edad de la primera experiencia de sexo forzado fue un poco mayor que la edad al primer abuso sexual. No obstante, 3 de cada 10 mujeres víctimas de sexo forzado tuvieron la primera experiencia antes de los 15 años y otras 3 de cada 10 entre los 15 y 19 años. El grupo de edad más vulnerable para el abuso sexual es el de 10 a 14 años, mientras que para el sexo forzado es el de 15 a 19 años. ${ }^{20}$
Nuevamente, estos datos son congruentes con los reportados por la PNC, pues por grupos de edad, las jóvenes de 0 a 17 años presentan mayor frecuencia como víctimas en todos los delitos contra la libertad sexual, a excepción de las violaciones, en los que la PNC clasifica de manera exclusiva a mayores de edad y dentro de estas, las que presentan el mayor número de denuncia son las víctimas de 18 a 30 años. Así, en el período de enero a octubre de 2013, la PNC registró 839 denuncias de violación en personas menores de 17 años. ${ }^{21}$ Igualmente preocupantes son los datos sobre víctimas de explotación sexual comercial que registran en sus estudios la Organización Internacional del Trabajo, puesto que muchas de las víctimas son personas entre los 14 a 16 años de edad, y en su mayoría son niñas. ${ }^{22}$

La encuesta FESAL también preguntó a las mujeres que reportaron sexo 
forzado o abuso sexual, quién la había obligado a estos actos. Para ambos tipos de violencia sexual -87 por ciento en los casos de sexo forzado y el 85 por ciento en casos de abuso sexual- los responsables resultaron ser personas conocidas de la víctima. Para las mujeres con experiencia de abuso sexual, entre las personas que identificaron con mayor frecuencia están: vecino, amigo u otro conocido ( 27 por ciento), exesposo/excompañero (17 por ciento), padrastro (9 por ciento), esposo/compañero actual (8 por ciento), tío ( 8 por ciento). En los casos del sexo forzado, los responsables que identificaron con mayor frecuencia fueron: exesposos/excompañeros (42 por ciento), esposo/compañero actual (24 por ciento), vecino, amigo u otros conocidos (12 por ciento), padrastro (5 por ciento), tío (3 por ciento)..23 Mientras que en el caso de los datos registrados por la $\mathrm{PNC}$ por violencia sexual, si bien en la mayoría de casos la relación entre la víctima y el agresor no está determinada, en los casos en los que se identifica a los agresores, prevalece el compañero y ex compañero de vida, novio, padrastro, padre y tíos. ${ }^{24}$

No obstante estas estadísticas, es importante tener en cuenta la dificultad de establecer la dimensión de la violencia sexual en El Salvador, puesto que las fuentes disponibles son, principalmente, las denuncias realizadas por las víctimas a través de diferentes instancias - FGR, ${ }^{25}$ PNC, ISDEMU, ${ }^{26}$ entre otras- $y$, por lo tanto, representan solo un porcentaje de la ocurrencia de violencia sexual. También hay que considerar que existen otros muchos casos que no son reportados ni denunciados por distintas causas a saber: por temor, vergüenza, indiferencia, falta de confianza en las instituciones. ${ }^{27}$

En esta misma línea, como bien se apunta, hay que considerar que en El Salvador existen diferencias entre los distintos datos reportados por las instituciones, puesto que no existe unificación de criterios de tipificación estadística entre estas, además de que no todas las instituciones iniciaron sus registros bajo los mismos criterios y los mismos años, por lo cual "cada institución reporta parcialmente la complejidad de la violencia sexual, de donde se desprende la importancia de la unificación de criterios para el manejo de expedientes y la comunicación interinstitucional". ${ }^{28}$

Asimismo, la Organización Internacional del Trabajo (OIT) también ha manifestado respecto a la explotación sexual comercial de niños, niñas y adolescentes que, no obstante que la pobreza en el hogar es un factor importante que empuja a los niños y niñas a ser víctimas de este fenómeno delictivo, la discriminación de género en la sociedad salvadoreña hace también especialmente vulnerables a las niñas de corta edad. ${ }^{29}$

II. Legislación salvadoreña relativa a la protección de la indemnidad y libertad sexual

\subsection{Constitución y leyes secundarias}

En El Salvador el derecho a la libertad está protegido constitucionalmente. Así, el Artículo 2 de la Constitución reconoce a la libertad como un derecho fundamental de la persona, $y$ en ese sentido, -y de conformidad con el Art. 1 de la Constitución-, es obligación del Estado salvadoreño asegurar 
a los habitantes de la República el goce de este derecho fundamental. Asimismo, en cuanto a los derechos de los niños, niñas y adolescentes, el Art. 34 del citado cuerpo legal supremo establece que todo menor tiene derecho a vivir en condiciones familiares y ambientales que le permitan su desarrollo integral, para lo cual tendrá la protección del Estado.

De igual forma, la Constitución salvadoreña concede el rango de leyes de la República a los tratados internacionales celebrados por El Salvador con otros Estados o con organismos internacionales. En este sentido, también se encuentran vigentes para el país diversos instrumentos relativos a la protección de la indemnidad y libertad sexual. ${ }^{30}$ (Cuadro 1)

Asimismo, existe legislación secundaria que busca garantizar los compromisos internacionales adquiridos por el Estado salvadoreño. Así, podemos citar a la Ley contra la Violencia Intrafamiliar (LCVI), vigente desde diciembre de 1996, la cual adopta entre sus fines el establecer mecanismos adecuados para prevenir, sancionar y erradicar la violencia intrafamiliar; así como aplicar las medidas preventivas, cautelares y de protección necesarias para garantizar la vida, integridad y dignidad de las víctimas de este tipo de violencia. ${ }^{31}$

De igual manera, la LCVI establece que la violencia sexual es una forma de violencia intrafamiliar, entendida esta como "acciones que obligan a una persona a mantener contactos sexualizados físico o verbales, o a participar en ellos, mediante la fuerza, intimidación, coerción, chantaje, soborno, manipulación, amenaza u otro mecanismo que anule o limite la voluntad personal. Igualmente, se considerará violencia sexual, el hecho de que la persona agresora obligue a la persona agredida a realizar alguno de estos actos con terceras personas". ${ }^{32}$

Para garantizar y proteger los derechos de las víctimas de violencia intrafamiliar la LCVI establece el procedimiento a seguir para la intervención de la jurisdicción de familia y los jueces de paz. Así, en virtud del Artículo 13 de la citada ley, toda persona que tenga conocimiento de un hecho constitutivo de violencia intrafamiliar, podrá denunciarlo o dar aviso a la Policía Nacional Civil, a los tribunales competentes y a la Procuraduría General de la República. En el caso de los funcionarios, médicos, farmacéuticos, enfermeros, maestros y demás personas que conozcan de hechos de violencia intrafamiliar en el ejercicio de su profesión o funciones; estos tienen la obligación de dar aviso a las autoridades correspondientes. 33

Con la denuncia o aviso recibido se da inicio al procedimiento en los Tribunales de Paz o Familia, en su caso. ${ }^{34}$ No obstante, es importante tener en cuenta -especialmente en lo relativo a la protección de la libertad e indemnidad sexual- que la LCVI establece que este procedimiento se aplicará sin perjuicio de la responsabilidad penal en la que pueden incurrir las personas responsables de violencia intrafamiliar. ${ }^{35}$ Esta disposición es relevante, puesto que -como estudiaremos infra-, la mayoría de atentados contra la libertad e indemnidad sexual están protegidos en la legislación penal y, por lo tanto, serán muy pocos los casos que podrán ser conocidos exclusivamente por la jurisdicción de familia, dada la relevancia del bien jurídico 
protegido. Pero incluso aquellos atentados contra la libertad e indemnidad sexual que no estuvieren contemplados por la legislación penal, pero que fuesen constitutivos de violencia intrafamiliar, pueden llegar a ser protegidos en el ámbito penal. Así, en el caso de que se hubiese agotado el procedimiento judicial establecido en la LCVI, queda configurado el tipo penal de Violencia Intrafamiliar regulado en el Artículo 200 del Código Penal.

Asimismo, el Artículo 42 de la LCVI regula que cuando se trate de hechos de violencia intrafamiliar sometidos a la jurisdicción penal, ambas jurisdicciones deberán intercambiar información directa sobre el estado del proceso a efecto de ser considerado en su resolución judicial.

Otra legislación relevante en materia de protección de la libertad sexual de la mujer es la Ley Especial Integral para una Vida Libre de Violencia para las Mujeres (LEIV), vigente desde el uno de enero de dos mil doce. Esta ley tiene como finalidad garantizar a las mujeres su derecho a una vida libre de violencia, así como el goce, ejercicio y protección de sus derechos fundamentales. ${ }^{36}$

En virtud del Artículo 9 de la citada Ley, se considera a la violencia sexual como un tipo de violencia contra la mujer, entendida esta como "toda conducta que amenace o vulnere el derecho de la mujer a decidir voluntariamente su vida sexual, comprendida en esta no solo el acto sexual sino toda forma de contacto o acceso sexual, genital o no genital, con independencia de que la persona agresora guarde o no relación conyugal, de pareja, social, laboral, afectiva o de parentesco con la mujer víctima”. En este sentido, entre otras medidas, esta Ley incorpora tipo penales para ciertas conductas atentatorias de la libertad sexual de las mujeres, a los cuales nos referiremos con más detalle Infra.

En cuanto a la protección de la indemnidad y libertad sexual de los niños, niñas y adolescentes, la Ley de Protección Integral de la Niñez y Adolescencia (LEPINA), cuenta con diversos Artículos que establecen el derecho de las niñas, niños y adolescentes a que se respete su integridad personal, la cual comprende la integridad física, psicológica, cultural, moral, emocional y sexual. ${ }^{37}$ En este sentido, establece la obligación del Estado salvadoreño de establecer políticas públicas y programas para la prevención, atención y erradicación del maltrato de las niñas, niños y adolescentes, entendido este como "toda acción u omisión que provoque o pueda provocar dolor, sufrimiento o daño a la integridad o salud física, psicológica, moral o sexual de una niña, niño o adolescente, por parte de cualquier persona, incluidos sus padres, madres u otros parientes, educadores y personas a cargo de su cuido, cualesquiera que sean los medios utilizados". ${ }^{38}$

Específicamente, el Artículo 55 de la citada Ley establece que todas las niñas, niños y adolescentes tienen el derecho a ser protegidos contra el abuso y explotación sexual, definiendo el abuso sexual como "toda conducta tipificada en el Código Penal, que atente contra la libertad e integridad sexual de una niña, niño o adolescente para sacar ventaja o provecho de cualquier clase o índole"; mientras que la explotación sexual es entendida como "cualquier forma de abuso sexual mediante retribución en 
dinero o en especie, con intermediación o sin ella, existiendo o no alguna forma de proxenetismo". Consecuentemente, la utilización, reclutamiento u oferta de niñas, niños y adolescentes para la prostitución, la producción o actuación pornográfica, son consideradas como casos de abuso y explotación sexual. En esta misma línea, la LEPINA establece que las niñas, niños y adolescentes tienen derecho a ser protegidos frente a la trata de personas, principalmente aquella que tenga como finalidad la explotación de la prostitución ajena u otras formas de explotación sexual, entre otras modalidades. ${ }^{39}$

\section{Cuadro 1}

\section{Instrumentos internacionales ratificados por El Salvador relacionados con la protección de la indemnidad y libertad sexual.}

\begin{tabular}{|c|c|c|c|}
\hline Instrumento internacional & $\begin{array}{l}\text { Fecha de ratificación por } \\
\text { el Estado salvadoreño }\end{array}$ & $\begin{array}{l}\text { Fecha de publicación } \\
\text { en Diario Oficial }\end{array}$ & $\begin{array}{l}\text { Artículos relacionados con la } \\
\text { indemnidad y libertad sexual }\end{array}$ \\
\hline $\begin{array}{l}\text { Convenio de Ginebra } \\
\text { relativo a la Protección de } \\
\text { Personas Civiles en Tiempo } \\
\text { de Guerra del } 12 \text { de agosto } \\
\text { de } 1949 .\end{array}$ & $10 / 12 / 52$ & $24 / 02 / 1953$ & $\begin{array}{l}\text { Art. 27. Las mujeres serán } \\
\text { especialmente amparadas } \\
\text { contra todo atentado a su } \\
\text { honor y, en particular, contra la } \\
\text { violación, contra el forzamiento } \\
\text { a la prostitución y contra todo } \\
\text { atentado a su pudor. }\end{array}$ \\
\hline $\begin{array}{l}\text { Convención Americana } \\
\text { sobre Derechos Humanos. }\end{array}$ & $23 / 06 / 78$ & $05 / 05 / 95$ & $\begin{array}{l}\text { Art. 6. Prohibición de la esclavitud } \\
\text { y servidumbre. } \\
\text { 1.- Nadie puede ser sometido a } \\
\text { esclavitud o servidumbre, y tanto } \\
\text { estas, como la trata de esclavos } \\
\text { y la trata de mujeres están } \\
\text { prohibidas en todas sus formas. }\end{array}$ \\
\hline $\begin{array}{l}\text { Protocolo Adicional a los } \\
\text { Convenios de Ginebra del } 12 \\
\text { de agosto de } 1949 \text { relativo } \\
\text { a la Protección de las } \\
\text { Víctimas de los Conflictos } \\
\text { Armados Internacionales } \\
\text { (Protocolo I). }\end{array}$ & $04 / 07 / 78$ & $28 / 08 / 78$ & $\begin{array}{l}\text { Art. 75. Garantías fundamentales. } \\
\text { 2.- Están y quedarán prohibidos } \\
\text { en todo tiempo y lugar los actos } \\
\text { siguientes, ya sean realizados } \\
\text { por agentes civiles o militares: b) } \\
\text { los atentados contra la dignidad } \\
\text { personal, en especial los tratos } \\
\text { humillantes y degradantes, la } \\
\text { prostitución forzada y cualquier } \\
\text { forma de atentado al pudor; }\end{array}$ \\
\hline
\end{tabular}




\section{Instrumento internacional}

Protocolo Adicional a los Convenios de Ginebra del 12 de agosto de 1949 relativo a la Protección de las Víctimas de los Conflictos Armados sin Carácter Internacional (Protocolo II). el Estado salvadoreño
Fecha de ratificación por Fecha de publicación

Artículos relacionados con la indemnidad y libertad sexual

Art. 4. Garantías fundamentales. 1. Todas las personas que no participen directamente en las hostilidades, o que hayan dejado de participar en ellas, estén o no privadas de libertad, tienen derecho a que se respeten su persona, su honor, sus convicciones y sus prácticas religiosas. Serán tratadas con humanidad en toda circunstancia, sin ninguna distinción de carácter desfavorable. Queda prohibido ordenar que no haya supervivientes.

2. Sin perjuicio del carácter general de las disposiciones que preceden, están y quedarán prohibidos en todo tiempo y lugar con respecto a las personas a que se refiere el párrafo 1:

e) los atentados contra la dignidad personal, en especial los tratos humillantes y degradantes, la violación, la prostitución forzada y cualquier forma de atentado al pudor;

f) la esclavitud y la trata de esclavos en todas sus formas.

Pacto Internacional de

Derechos Civiles y Políticos.

$23 / 11 / 79$

$23 / 11 / 79$

Art. 8.- 1. Nadie estará sometido a esclavitud. La esclavitud y la trata de esclavos estarán prohibidas en todas sus formas.

\begin{tabular}{llll}
\hline Convención sobre la & $02 / 06 / 81$ & $09 / 06 / 81$
\end{tabular}

Eliminación de todas las

Formas de Discriminación

contra la Mujer (CEDAW).
Art. 5.- Los Estados Partes tomarán todas las medidas apropiadas para:

a) Modificar los patrones socioculturales de conducta de hombres y mujeres, con miras a alcanzar la eliminación de los prejuicios y las prácticas consuetudinarias y de cualquier otra índole que estén basados en la idea de la inferioridad o superioridad de cualquiera de los sexos o en funciones estereotipadas de hombres y mujeres;

Art. 6.- Los Estados Partes tomarán todas las medidas apropiadas, incluso de carácter legislativo, para suprimir todas las formas de trata de mujeres y explotación delaprostitución delamujer. 


\begin{tabular}{lcc} 
Instrumento internacional & $\begin{array}{c}\text { Fecha de ratificación por } \\
\text { el Estado salvadoreño }\end{array}$ & $\begin{array}{c}\text { Fecha de publicación } \\
\text { en Diario Oficial }\end{array}$ \\
\hline
\end{tabular}

\begin{tabular}{lll}
\hline Convención sobre los & 27/04/90 & 09/05/90
\end{tabular}

Derechos del Niño.
Artículos relacionados con la indemnidad y libertad sexual

Art. 19.- 1. Los Estados Partes adoptarán todas las medidas legislativas, administrativas, sociales y educativas apropiadas para proteger al niño contra toda forma de perjuicio o abuso físico o mental, descuido o trato negligente, malos tratos o explotación, incluido el abuso sexual, mientras el niño se encuentra bajo la custodia de los padres, de un representante legal o de cualquier otra persona que los tenga a su cargo.

Art. 34.- Los Estados Partes se comprometen a proteger al niño contra las formas de explotación y abuso sexuales.

Con este fin los Estados Partes tomarán, en particular, todas las medidas de carácter nacional, bilateral, y multilateral que sean necesarias para impedir:

a) La incitación o la coacción para que un niño se dedique a cualquier actividad sexual ilegal; b) La explotación del niño en la prostitución u otras prácticas sexuales ilegales;

c) La explotación del niño en espectáculos 0 materiales pornográficos.

Convención Interamericana

$23 / 08 / 95$

$23 / 08 / 95$

para Prevenir, Sancionar y

Erradicar la Violencia Contra

la Mujer (Convención Belém

do Pará).
Art. 2. Se entenderá que violencia contra la mujer incluye la violencia física, sexual y psicológica:

a. Que tenga lugar dentro de la familia o unidad doméstica o en cualquier otra relación interpersonal, ya sea que el agresor comparta o haya compartido el mismo domicilio que la mujer, y que comprende, entre otros, violación, maltrato y abuso sexual;

b. Que tenga lugar en la comunidad y sea perpetrada por cualquier persona y que comprende, entre otros, violación, abuso sexual, tortura, 
Instrumento internacional
Fecha de ratificación por el Estado salvadoreño
Fecha de publicación en Diario Oficial

\section{Artículos relacionados con la indemnidad y libertad sexual}

trata de personas, prostitución forzada, secuestro y acoso sexual en el lugar de trabajo, así como en instituciones educativas, establecimientos de salud 0 cualquier otro lugar.

Art. 7. Los Estados Partes condenan a todas las formas de violencia contra la mujer y convienen en adoptar, por todos los medios apropiados y sin dilaciones, políticas orientadas a prevenir, sancionar y erradicar dicha violencia y en llevar a cabo lo siguiente:

c. Incluir en su legislación interna normas penales, civiles y administrativas, así como las de otra naturaleza que sean necesarias para prevenir, sancionar y erradicar la violencia contra la mujer y adoptar las medidas administrativas apropiadas que sean del caso.

Convenio 182 de la OIT 15/06/00 18/07/00 Art. 3.- A los efectos del presente Convenio, la expresión "las peores formas de trabajo infantil" abarca:

b) La utilización, el reclutamiento - la oferta de niños para la prostitución, la producción de pornografía o actuaciones pornográficas;

\footnotetext{
Protocolo para Prevenir, Reprimir y Sancionar la Trata de Personas, especialmente Mujeres y Niños, que complementa la Convención de las Naciones Unidas contra la Delincuencia Organizada Transnacional.
}

$18 / 12 / 03$

$23 / 12 / 03$

Art. 1.-Todo Miembro que ratifique el presente Convenio deberá adoptar medidas inmediatas y eficaces para conseguir la prohibición y la eliminación de las peores formas de trabajo infantil con carácter de urgencia.

Art. 3.- Definiciones. Para los fines del Presente Protocolo:

a) Por "trata de personas" se entenderá la captación, el transporte, el traslado, la acogida - la recepción de personas, recurriendo a la amenaza o al uso 
Instrumento internacional

Fecha de ratificación por el Estado salvadoreño
Fecha de publicación en Diario Oficial

Artículos relacionados con la indemnidad y libertad sexual

de la fuerza u otras formas de coacción, al rapto, al fraude, al engaño, al abuso de poder o de una situación de vulnerabilidad o a la concesión o recepción de pagos o beneficios para obtener el consentimiento de una persona que tenga autoridad sobre otra, con fines de explotación. Esa explotación incluirá, como mínimo, la explotación de la prostitución ajena u otras formas de explotación sexual, los trabajos o servicios forzados, la esclavitud o las prácticas análogas a la esclavitud, la servidumbre o la extracción de órganos;

Art. 5. Penalización. 1. Cada Estado Parte adoptará las medidas legislativas y de otra índole que sean necesarias para tipificar como delito en su derecho interno las conductas enunciadas en el Artículo 3 del presente Protocolo, cuando se cometan intencionalmente.

Protocolo facultativo
de la Convención sobre
los Derechos del Niño
relativo a la venta de
niños, la prostitución
infantil y la utilización de
niños en la pornografía.

25/02/04

$23 / 03 / 04$
Art. 3.- 1. Todo Estado Parte adoptará medidas para que, como mínimo, los actos y actividades que a continuación se enumeran queden íntegramente comprendidos en su legislación penal, tanto si se han cometido dentro como fuera de sus fronteras, o si se han perpetrado individual o colectivamente:

a) En relación con la venta de niños, en el sentido en que se define en el Artículo 2:

i) Ofrecer, entregar o aceptar, por cualquier medio, un niño con fines de:

a. Explotación sexual del niño;

b) La oferta, posesión, adquisición o entrega de un niño con fines de prostitución, en el sentido en que se define en el Artículo 2; 


Instrumento internacional $\begin{gathered}\text { Fecha de ratificación por } \\ \text { el Estado salvadoreño }\end{gathered} \quad \begin{gathered}\text { Fecha de publicación } \\ \text { en Diario Oficial }\end{gathered}$

Artículos relacionados con la indemnidad y libertad sexual

c) La producción, distribución, divulgación, importación, exportación, oferta, venta o posesión, con los fines antes señalados, de pornografía infantil, en el sentido en que se define en el Artículo 2.

\begin{tabular}{lll}
\hline Convención & \multirow{2}{*}{$17 / 03 / 05$} & Art. 2. Esta Convención se \\
Interamericana sobre & & aplicará a cualquier menor \\
Tráfico Internacional de & que se encuentre o resida \\
Menores & habitualmente en un Estado \\
& Parte al tiempo de la comisión de \\
& un acto de tráfico internacional \\
& contra dicho menor.
\end{tabular}

Para los efectos de la presente Convención.

b) "Tráfico internacional de menores" significa la substracción, el traslado o la retención, o la tentativa de substracción, traslado o retención, de un menor con propósitos o medios ilícitos.

c) "Propósitos ilícitos" incluyen, entre otros, prostitución, explotación sexual, servidumbre o cualquier otro propósito ilícito, ya sea en el Estado de residencia habitual del menor 0 en el Estado Parte en el que el menor se halle localizado.

Art. 7. Los Estados Parte se comprometen a adoptar medidas eficaces, conforme a su derecho interno, para prevenir y sancionar severamente el tráfico internacional de menores definido en esta Convención.

Fuente: Elaboración propia a partir de información sobre instrumentos internacionales ratificados por El Salvador disponible en http://www. jurisprudencia.gob.sv/.

\subsection{Legislación penal}

En El Salvador la indemnidad y la libertad sexual están protegidas principalmente por el Código Penal (CP $)^{40}$ en el Libro II: Parte Especial: De los delitos y sus penas, Título IV: Delitos contra la libertad sexual. A su vez el Título contiene 4 Capítulos: Capítulo I: 
De la Violación y otras agresiones sexuales, Capítulo II: Del Estupro, Capítulo III: Otros ataques a la libertad sexual, Capítulo IV: Disposición común. Los delitos regulados dentro del Título IV son los descritos en la el Cuadro 2.

Dado el nombre del Título podemos interpretar que el bien jurídico protegido por los delitos contenidos en este es la libertad sexual, entendida esta como "aquella parte de la libertad referida al ejercicio de la propia sexualidad, en el sentido de disposición sexual sobre el propio cuerpo".41 Esta libertad sexual puede ser ejercida en dos vertientes. Una positiva, que consiste en la libertad que se tiene al decidir implicarse libremente en una situación sexual con otra persona; y una negativa, en cuanto a la libertad de no implicarse en un contexto sexual..$^{42}$ Incluso, la protección de la libertad sexual abarca los supuestos en que el consentimiento se encuentra viciado, se distorsiona o está ausente. ${ }^{43}$

No obstante, la consideración de la libertad sexual como bien jurídico protegido ha sido debatida en relación de los delitos de índole sexual que perjudican a personas menores de edad, puesto que la libertad sexual como una manifestación de la facultad general de autodeterminación voluntaria en la esfera sexual no es posible en las personas menores de edad, pues estas no poseen la capacidad de consentir o rechazar las intromisiones en el ámbito personal de la libertad sexual. ${ }^{44}$ En respuesta a esta crítica, se ha planteado la interpretación de la libertad sexual desde una concepción negativa o estática, y desde esta concepción la libertad sexual conlleva asimismo una restricción que obliga a todos los individuos de abstenerse a mantener contactos sexuales con quienes no prestan su consentimiento, o que no están capacitados para expresarlo. ${ }^{45}$ Este sería en el caso de las personas menores de edad e incapaces, ${ }^{46}$ ya que estas carecen de esta libertad por las características propias de su desarrollo físico y psíquico, el cual no les permite comprender el significado de los actos sexuales, por lo que carecen de la necesaria autonomía para determinar libremente su comportamiento sexual, incluso cuando estos externan su voluntad hacia el comportamiento sexual. 47

Mientras que otro sector doctrinal considera que en los delitos que castigan las conductas sexuales cometidas contra personas menores de edad el bien jurídico tutelado es propiamente su indemnidad sexual. En este sentido, afirma que este bien jurídico se ajusta mucho más precisamente al contenido de lo injusto de estos delitos y lo libera en parte de sus fuertes raíces morales. En similar forma se han expresado al referirse a delitos de índole sexual contra personas menores de edad, puesto que consideran que se protege su indemnidad sexual con el fin de lograr la adecuada educación sexual y socialización de estos. Asimismo, la jurisprudencia del Tribunal de Sentencia de San Vicente ha considerado que lo que se tutela con la protección de la indemnidad sexual de las personas menores de 18 años es su libertad futura a través de la protección del normal desarrollo y evolución de su personalidad, para que, cuando sea adulto, decida en libertad su comportamiento sexual. ${ }^{48}$

Otro sector de la doctrina considera que la integridad sexual es el bien jurídico que mejor logra sortear las discrepancias en torno del bien jurídico libertad sexual, puesto que abarca tanto a la libertad 


\section{Cuadro 2}

\section{Articulado contenido en el Título IV del Código Penal: Delitos contra la libertad sexual.}

\begin{tabular}{|c|c|}
\hline Capítulo & Artículo \\
\hline Capítulo I: De la violación y otras agresiones sexuales. & $\begin{array}{l}\text { Art. 158. Violación. } \\
\text { Art. 159. Violación en menor o incapaz. } \\
\text { Art. 160. Otras agresiones sexuales. } \\
\text { Art. 161. Agresión sexual en menor e incapaz. } \\
\text { Art. 162. Violación y agresión sexual agravada. }\end{array}$ \\
\hline Capítulo II: Del estupro. & $\begin{array}{l}\text { Art. 163. Estupro. } \\
\text { Art. 164. Estupro por prevalimiento. }\end{array}$ \\
\hline Capítulo III: Otros ataques a la libertad sexual. & $\begin{array}{l}\text { Art. 165. Acoso sexual. } \\
\text { Art. 166. Acto sexual diverso. } \\
\text { Art. 167. Corrupción de menores e incapaces. } \\
\text { Art. 168. Corrupción agravada. } \\
\text { Art. 169. Inducción, promoción y favorecimiento de } \\
\text { actos sexuales o eróticos. } \\
\text { Art. 169-A. Remuneración por actos sexuales o eróticos. } \\
\text { Art. 170. Determinación a la prostitución } \\
\text { Art. 170-A. Oferta y demanda de prostitución ajena. } \\
\text { Art. 171. Exhibiciones obscenas. } \\
\text { Art. 172. Pornografía } \\
\text { Art. 173. Utilización de personas menores de dieciocho } \\
\text { años e incapaces o deficientes mentales en pornografía. } \\
\text { Art. 173-A. Posesión de pornografía. } \\
\text { Art. 173-B. Agravantes. }\end{array}$ \\
\hline Capítulo IV: Disposición común. & Art. 174. Indemnizaciones especiales. \\
\hline
\end{tabular}

Fuente: Elaboración propia a partir del Código Penal salvadoreño.

sexual de los individuos adultos como a la indemnidad sexual de las personas menores de edad e incapaces que les permitirá en el futuro tener la capacidad para decidir libremente sobre sus relaciones sexuales. Así, la integridad sexual se identifica con todas aquellas agresiones dirigidas contra la libertad, indemnidad y desarrollo de la sexualidad del sujeto pasivo en su dimensión más amplia, que se relaciona directamente con la autonomía y dignidad inmanente de la persona humana. ${ }^{49}$

En conclusión, tal como manifiestan, si bien el legislador salvadoreño ha colocado en el Título que contiene a los delitos contra la libertad sexual a aquellos delitos cometidos contra la esfera sexual de las personas menores de edad, consideramos que ya que en este Título no solo se regulan delitos contra la libertad sexual, sino también contra la indemnidad sexual, debería modificarse el Título IV con el nombre "Delitos contra la Libertad e Indemnidad Sexual”. En cuanto a los delitos contemplados en el Capítulo I, relativo a la violación y otras agresiones sexuales, sus principales elementos están descritos en el Cuadro 3.

En relación a la regulación establecida en este Capítulo resulta relevante resaltar que tanto en el delito de violación como en el 
de agresión sexual se protege de manera especial, junto con las personas menores de 15 años, a las personas con enajenación mental, en estado de inconsciencia o con incapacidad para resistir. Si bien el Código de Familia en el Art. 293 regula que pueden ser declaradas incapaces las personas con enfermedad mental crónica e incurable, aunque existan intervalos lúcidos $\mathrm{y}$, las personas con sordera, salvo que esta pueda entender y darse a entender de manera indudable; no obstante, el Código Penal no específica que el sujeto pasivo deba haber sido declarado incapaz.

De igual forma, resulta relevante el hecho de que cuando el delito de agresión sexual es cometido mediante acceso carnal bucal, o por introducción de objetos en vía vaginal o anal, la pena se equipara a la misma que recibe el delito de violación. ${ }^{50}$ Así, la pena establecida para el tipo básico de violación (Art. 158) y para el delito de otras agresiones sexuales con acceso carnal bucal o introducción de objetos en vía vaginal o anal (Art. 160 inc. $2 .^{\circ}$ ) tienen una sanción de seis a diez años de prisión; mientras que si son cometidos en personas menores de quince años de edad, la sanción corresponde a una pena de prisión de catorce a veinte años. Estas sanciones son las más altas establecidas en el grupo de delitos contra la libertad sexual, con lo que se deduce que el legislador penal ha considerado que el acceder a una persona ya sea por vía vaginal o anal, e independientemente de la forma en que haya sido accedida - de forma carnal, bucal o mediante la introducción de objetos-, constituye la vulneración más grave a la libertad sexual. Asimismo, el legislador penal ha establecido la misma pena que se regula para la violación al delito de determinación a la prostitución (Art. 170) y ha sancionado con un rango cercano de pena a los delitos de estupro (Art. 163) cuatro a diez años de prisión-, y estupro por prevalimiento (Art. 164) — seis a doce años de prisión. ${ }^{51}$

No obstante que el desvalor de la acción de acceder a una persona de forma violenta o contra su consentimiento justifica la gravedad de la sanción, el establecer a esta conducta como el hecho más gravoso contra la libertad sexual ha recibido sus críticas. En este sentido, para dar mayor importancia a la forma en que la víctima fue vulnerada en su libertad sexual deja entrever un "sesgo moral" en lugar de valorar la magnitud del daño ocasionado por dicha vulneración. ${ }^{52}$ Asimismo, con esta distinción "se refuerza el sometimiento hacia las mujeres y reduce su campo de acción a una sanción que sigue estando relacionada, al menos en la aplicación de medidas, a la restauración de la honra o la moral y no a la libertad sexual lesionada o su indemnidad". 53

Asimismo, para este autor el hecho de que el delito de otras agresiones sexuales sea sancionado con menor pena que la violación refuerza la creencia de que el mayor daño de una agresión sexual es la penetración del cuerpo, generándose así "la impresión" de que la agresión sexual no es una acción violenta aunque sí lesiva. Por tanto, esta distinción es atentatoria de los derechos de las mujeres víctimas de violencia sexual, en cuanto a que el efecto de la menor sanción de las agresiones sexuales podría traer como consecuencia el aumento de probabilidades de alentar la impunidad al imponer penas distintas por delitos que causan el mismo impacto en las víctimas. En conclusión añade-, es necesario que más que poner la 
atención en si ha habido o no penetración no consentida de forma violenta, debería darse énfasis a los daños de naturaleza física y emocional infringidos en la víctima. ${ }^{54}$

En cuanto al Capítulo II: Del Estupro, este contiene dos Artículos, a saber: el Artículo 163 que regula el delito de estupro y el Artículo 164, que regula el delito de estupro por prevalimiento, siendo sus principales elementos los señalados en Cuadro 4.

De la regulación del delito de estupro se infiere quela edad permitida porla legislación penal para consentir sexualmente es a partir de los 15 años. No obstante, si observamos el Artículo 159, que regula el delito de violación en menor o incapaz, este establece que será sancionado por este delito el que tuviere acceso carnal por vía vaginal o anal con menor de quince años. En este sentido, la redacción de ambos Artículos, dejan un problema de interpretación respecto de aquellas personas que tengan exactamente 15 años, puesto que si en el caso de que esta persona tenga relaciones sexuales consentidas, cabría preguntarse cuál sería el delito que comete la persona que ha accedido carnalmente con esta persona menor. Así, al no ser menor de 15 años, no se configuraría el delito de violación en menor o incapaz; pero tampoco se configuraría el delito de estupro - tanto por engaño como por prevalimimiento-, al no ser el sujeto pasivo mayor de 15 años. Dicha confusión se vuelve más evidente al comparar las edades con las establecidas en el delito de acto sexual diverso regulado en el Artículo 166 $\mathrm{CP}$, cuya discusión abordaremos infra.

El Capítulo III contiene a los delitos considerados como "otros ataques a la libertad sexual" y cuyos elementos principales se detallan en el Cuadro 5. En este Capítulo se encuentran regulados muchos delitos relacionados con la explotación sexual, siendo los delitos de corrupción de menores e incapaces (Art. 167), determinación a la prostitución (Art. 170) y utilización de personas menores de dieciocho años e incapaces o deficientes mentales en pornografía (Art. 173), los que contienen las penas más graves de prisión del Capítulo, penas equiparables al delito de violación.

Es relevante destacar entre los Artículos regulados en este Capítulo al Artículo 166, que sanciona el acto sexual diverso. Así, el tipo penal básico establece que se comete el delito cuando mediante engaño se realizare cualquier acto sexual diverso del acceso carnal con persona mayor de quince y menor de dieciocho años. En este aspecto el Artículo se encuadra con el límite legal establecido en los demás Artículos de este Capítulo. No obstante, en su inciso segundo, el Artículo 166 establece que si el acto sexual fuese realizado con persona menor de dieciséis años, aún con su consentimiento, será sancionado con prisión de ocho a doce años. Este rango de edad genera confusión en cuanto a cómo debemos interpretar los límites legales de consentimiento sexual. Así, si analizamos el delito de estupro (Art. 163), observamos que este se comete mediante engaño con persona mayor de quince años. La interpretación que se hace al respecto es que a partir de los quince años la persona puede consentir tener relaciones sexuales, castigándose únicamente el hecho de que esta hubiese sido engañada para tal fin. Pero siendo que el delito de acto sexual diverso, cuya configuración típica es parecida con la del delito de estupro, 
diferenciándose básicamente en que en el primero es necesario que exista acceso carnal mientras que en el segundo tiene que ser cualquier acto sexual distinto al acceso carnal; en este sentido, pareciera que con la fórmula "mayor de quince años" el autor se refiere a las personas que tengan 16 años o más y no 15 años, como podríamos haber interpretado inicialmente en el delito de estupro.

Luego, haciendo una autointegración del Código Penal, podría interpretarse que esta fórmula es aplicable a los delitos que regulan un rango de edad similar, a saber, estupro (Art. 163), estupro por prevalimiento (Art. 164). La falta de coordinación entre las edades establecidas en estos tipos penales puede generar confusiones que, dadas las garantías establecidas en el derecho penal, deberán resolverse con una interpretación restrictiva que sea favorable al reo. Por lo tanto, se sugiere revisar los márgenes de edad regulados en este Capítulo, con el fin de evitar interpretaciones que vayan en contra del espíritu del legislador penal.

Asimismo, llama la atención que delitos cuyo perjuicio en la integridad de la víctima -tanto física, sexual como emocionalpuede ser elevado, su sanción se haya determinado exclusivamente cuando el sujeto pasivo sea menor de dieciocho años. Así los delitos de inducción, promoción y favorecimiento de actos sexuales y eróticos (Art. 169), remuneración por actos sexuales o eróticos (Art. 169-A) y utilización de personas menores de dieciocho años e incapaces o deficientes mentales en pornografía (Art. 173) solo se castigan las conductas típicas realizadas sobre niños, niñas o adolescentes. Por tanto, en los delitos regulados en el Código Penal se han dejado sin sanción a estas conductas cuando sean cometidas en personas mayores de edad.

Acertadamente, este vacío ha sido suplido de manera parcial por la LEIV en su Título II: Delitos y sanciones, Capítulo I: Delitos y sanciones; que castiga penalmente estas conductas cuando sean cometidas en mujeres mayores de edad. Los delitos regulados en este Título vinculados con la violencia sexual se detallan en el Cuadro 6. No obstante el reconocimiento de la sanción de estas conductas cuando son realizadas en mujeres mayores de edad, resulta cuestionable que el legislador penal salvadoreño haya dejado por fuera la sanción de estas conductas cuando sean realizadas en personas del sexo masculino. Así, aunque en menor número, estas personas también pueden ser víctimas de este tipo de delitos, sobre todo, aquellos cuya identidad de género esté asociada con el género femenino, y por tanto, sufren en similar medida los estereotipos y discriminaciones dados a las mujeres.

Finalmente, queremos Ilamar la atención en el único Artículo regulado en el Capítulo IV: Disposición común, del Título IV: Delitos contra la libertad sexual, del Código Penal. El Artículo 174 establece las indemnizaciones especiales en las que deberán ser condenados los autores de los delitos contenidos en los Capítulos I y II del Título IV, a saber: 1) sufragar todos los gastos en que hubiere incurrido la víctima en concepto de atención médica y psiquiátrica o psicológica; y 2) proveer a la víctima de manutención completa por el término de la incapacidad médica.

A pesar de lo acertado que pueda ser 
este Artículo en cuanto a establecer la obligación del sujeto activo de indemnizar a la víctima, son cuestionables dos puntos. El primero, en cuanto a la exclusiva mención de los Capítulos I y II del Título IV, los cuales regulan respectivamente a la violación y otras agresiones sexuales y al estupro. Si bien para estos delitos representan "una profunda ofensa en los sentimientos más íntimos del sujeto pasivo" y por esta especial gravedad se justifica esta mención expresa de estos de delitos; ${ }^{55}$ no se comprende por qué el legislador consideró dejar fuera de esta disposición a todos los Artículos regulados en el Capítulo III, el cual contiene el mayor número de delitos, muchos de ellos relacionados con la explotación sexual comercial, principalmente en personas menores de edad. Si bien esta omisión queda solventada con la disposición general que hace el legislador penal en el Título VI: Consecuencias civiles del hecho punible (Arts. 114-125), sugerimos la modificación de este Artículo para que se comprenda en el mismo al Capítulo III del Título IV del Código Penal, lo cual estaría en consonancia con el espíritu del legislador en cuanto a la protección integral de la libertad e indemnidad sexual de todas las personas.

Un segundo punto de crítica al Artículo 174 es en cuanto a su referencia a una sola forma de indemnización relacionada de manera exclusiva a los gastos efectuados en atención médica, psiquiátrica o psicológica y la manutención durante la incapacidad médica. Así como acertadamente manifiesta se dejan por fuera aquellos daños emocionales sufridos por la víctima, que no necesariamente causan incapacidad médica. Asimismo, apunta el autor, no es posible cuantificar los daños y la indemnización de los mismos bajo un criterio reduccionista puramente biomédico, siendo necesario que se impongan medidas que en realidad logren una restauración efectiva para la víctima. ${ }^{56}$

En conclusión, también se hace necesario revisar la redacción del Artículo 174 del Código Penal, para que en este se puedan incluir todos los delitos que atentan contra la integridad y la libertad sexual, así como dotar de un enfoque restaurativo de derecho a las indemnizaciones en él establecidas. 


\section{Cuadro 3}

Principales elementos de los delitos regulados en el Código Penal, Capítulo I: De la Violación y otra Agresiones Sexuales.

\begin{tabular}{|c|c|c|c|c|}
\hline Delito & Conducta típica & Sujeto activo & Sujeto pasivo & $\begin{array}{l}\text { Consecuencia } \\
\text { jurídica }\end{array}$ \\
\hline \multirow[t]{8}{*}{$\begin{array}{l}\text { Art. } 158 \\
\text { Violación. }\end{array}$} & $\begin{array}{l}\text { Acceso carnal por vía } \\
\text { vaginal o anal mediante } \\
\text { violencia. }\end{array}$ & Cualquier persona. & $\begin{array}{l}\text { Persona mayor de } \\
18 \text { años. }\end{array}$ & $\begin{array}{l}6 \text { a } 10 \text { años de } \\
\text { prisión. }\end{array}$ \\
\hline & & & $\begin{array}{l}\text { Persona de entre } \\
\text { los } 15 \text { años y menor } \\
\text { de } 18 \text { años de edad. } \\
\text { Prole del cónyuge } \\
\text { o conviviente. }\end{array}$ & $\begin{array}{l}10 \text { años y un día a } 13 \\
\text { años y } 4 \text { meses de } \\
\text { prisión por } \\
\text { agravante del } \\
\text { Art. } 162 \text {. }\end{array}$ \\
\hline & & $\begin{array}{l}\text { Ascendiente, } \\
\text { descendiente, } \\
\text { hermanos, } \\
\text { adoptantes, } \\
\text { adoptados. }\end{array}$ & Cualquier persona. & $\begin{array}{l}10 \text { años y un día a } 13 \\
\text { años y } 4 \text { meses de } \\
\text { prisión por } \\
\text { agravante del } \\
\text { Art. } 162 \text {. }\end{array}$ \\
\hline & & $\begin{array}{l}\text { Autoridad pública. } \\
\text { Persona que } \\
\text { tuviere bajo su } \\
\text { custodia a la } \\
\text { víctima. }\end{array}$ & & \\
\hline & & $\begin{array}{l}\text { Persona encargada } \\
\text { de la guarda, } \\
\text { protección o } \\
\text { vigilancia de la } \\
\text { víctima. }\end{array}$ & & \\
\hline & $\begin{array}{l}\text { Ejecutada con el } \\
\text { concurso de dos o } \\
\text { más personas. }\end{array}$ & Cualquier persona. & Cualquier persona. & $\begin{array}{l}10 \text { años y un día a } 13 \\
\text { años y } 4 \text { meses de } \\
\text { prisión por } \\
\text { agravante del }\end{array}$ \\
\hline & $\begin{array}{l}\text { Haciendo uso de } \\
\text { medios, modos o } \\
\text { instrumentos } \\
\text { especialmente brutales, } \\
\text { degradantes o } \\
\text { vejatorios. }\end{array}$ & & & Art. 162. \\
\hline & $\begin{array}{l}\text { Con abuso de relaciones } \\
\text { domésticas o de } \\
\text { confianza derivada de } \\
\text { relaciones de trabajo. }\end{array}$ & & & \\
\hline
\end{tabular}




\begin{tabular}{|c|c|c|c|c|}
\hline Delito & Conducta típica & Sujeto activo & Sujeto pasivo & $\begin{array}{l}\text { Consecuencia } \\
\text { jurídica }\end{array}$ \\
\hline $\begin{array}{l}\text { Art. } 159 \\
\text { Violación en } \\
\text { menor o } \\
\text { incapaz. }\end{array}$ & $\begin{array}{l}\text { Acceso carnal por vía } \\
\text { vaginal o anal. }\end{array}$ & Cualquier persona. & $\begin{array}{l}\text { Persona menor de } \\
15 \text { años de edad. } \\
\text { Persona que sufra } \\
\text { enajenación mental. } \\
\text { En estado de } \\
\text { inconsciencia. } \\
\text { Con incapacidad } \\
\text { de resistir. }\end{array}$ & $\begin{array}{l}14 \text { a } 20 \text { años } \\
\text { de prisión. }\end{array}$ \\
\hline
\end{tabular}

Acceso carnal por vía vaginal o anal.
Cualquier persona. Prole del cónyuge o 20 años y un día a conviviente menor 26 años y 8 meses de 15 años de edad, de prisión por o que sufra agravante del enajenación mental, Art. 162.

o en estado de inconsciencia, o con incapacidad de resistir.

\begin{tabular}{|c|c|c|}
\hline $\begin{array}{l}\text { Ascendiente, } \\
\text { descendiente, } \\
\text { hermanos, } \\
\text { adoptantes, } \\
\text { adoptados. }\end{array}$ & \multirow{2}{*}{$\begin{array}{l}\text { Persona menor de } \\
15 \text { años de edad. } \\
\text { Persona que sufra } \\
\text { enajenación mental. } \\
\text { En estado de } \\
\text { inconsciencia. } \\
\text { Con incapacidad } \\
\text { de resistir. }\end{array}$} & \multirow[t]{2}{*}{$\begin{array}{l}20 \text { años y un día a } \\
26 \text { años y } 8 \text { meses } \\
\text { de prisión por } \\
\text { agravante del } \\
\text { Art. } 162 \text {. }\end{array}$} \\
\hline $\begin{array}{l}\text { Autoridad pública. } \\
\text { Persona que } \\
\text { tuviere bajo su } \\
\text { custodia a la } \\
\text { víctima. }\end{array}$ & & \\
\hline
\end{tabular}

Persona encargada de la guarda, protección o vigilancia de la víctima.

Ejecutada con el concurso de dos o más personas. Cualquier persona. 15 años de edad. $\quad 26$ años y 8 meses Persona que sufra de prisión por enajenación mental. agravante del En estado de Art. 162. inconsciencia. Con incapacidad de resistir. 


\begin{tabular}{ll} 
Delito & Conducta típica \\
\hline $\begin{array}{l}\text { Art. 160 Otras } \\
\text { agresiones }\end{array}$ & $\begin{array}{l}\text { Realizar en otra persona } \\
\text { sexuales. }\end{array}$ \\
& $\begin{array}{l}\text { sexual que no sea } \\
\text { constitutiva de } \\
\text { violación. }\end{array}$
\end{tabular}

Sujeto activo

Sujeto pasivo

Consecuencia jurídica

Cualquier persona. Cualquier persona. 3 a 6 años de prisión.

Persona de entre 6 años y un día a 8
los 15 años y menor años de prisión por de 18 años de edad. agravante del Art. 162.

Prole del cónyuge o conviviente.

\begin{tabular}{|c|c|c|c|}
\hline & $\begin{array}{l}\text { Ascendiente, } \\
\text { descendiente, } \\
\text { hermanos, } \\
\text { adoptantes, } \\
\text { adoptados. }\end{array}$ & Cualquier persona. & $\begin{array}{l}6 \text { años y un día a } 8 \\
\text { años de prisión por } \\
\text { agravante del } \\
\text { Art. } 162 .\end{array}$ \\
\hline & $\begin{array}{l}\text { Autoridad pública. } \\
\text { Persona que } \\
\text { tuviere bajo su } \\
\text { custodia a la } \\
\text { víctima. }\end{array}$ & & \\
\hline & $\begin{array}{l}\text { Persona encargada } \\
\text { de la guarda, } \\
\text { protección o } \\
\text { vigilancia de la } \\
\text { víctima. }\end{array}$ & & \\
\hline $\begin{array}{l}\text { Agresión sexual que no } \\
\text { sea constitutiva de } \\
\text { violación ejecutada con } \\
\text { el concurso de dos o } \\
\text { más personas; o } \\
\text { haciendo uso de medios, } \\
\text { modos o instrumentos } \\
\text { especialmente brutales, } \\
\text { degradantes o } \\
\text { vejatorios; o con abuso } \\
\text { de relaciones } \\
\text { domésticas o de } \\
\text { confianza derivada de } \\
\text { relaciones de trabajo. }\end{array}$ & Cualquier persona. & Cualquier persona. & $\begin{array}{l}6 \text { años y un día a } 8 \\
\text { años de prisión por } \\
\text { agravante del } \\
\text { Art. } 162 \text {. }\end{array}$ \\
\hline \multirow{2}{*}{$\begin{array}{l}\text { Agresión sexual con } \\
\text { acceso carnal bucal, o } \\
\text { introducción de objetos } \\
\text { en vía vaginal o anal. }\end{array}$} & \multirow[t]{2}{*}{ Cualquier persona. } & Cualquier persona. & $\begin{array}{l}6 \text { a } 10 \text { años } \\
\text { de prisión. }\end{array}$ \\
\hline & & $\begin{array}{l}\text { Persona de entre } \\
\text { los } 15 \text { años y menor } \\
\text { de } 18 \text { años de edad. } \\
\text { Prole del cónyuge o } \\
\text { conviviente. }\end{array}$ & $\begin{array}{l}10 \text { años y un día a } 13 \\
\text { años y } 4 \text { meses de } \\
\text { prisión por } \\
\text { agravante del } \\
\text { Art. } 162 .\end{array}$ \\
\hline
\end{tabular}




\begin{tabular}{|c|c|c|c|c|}
\hline Delito & Conducta típica & Sujeto activo & Sujeto pasivo & $\begin{array}{l}\text { Consecuencia } \\
\text { jurídica }\end{array}$ \\
\hline & & $\begin{array}{l}\text { Ascendiente, } \\
\text { descendiente, } \\
\text { hermanos, } \\
\text { adoptantes, } \\
\text { adoptados. }\end{array}$ & \multirow[t]{2}{*}{ Cualquier persona } & \multirow[t]{2}{*}{$\begin{array}{l}10 \text { años y un día a } 13 \\
\text { años y } 4 \text { meses de } \\
\text { prisión por } \\
\text { agravante del } \\
\text { Art. } 162 \text {. }\end{array}$} \\
\hline & & $\begin{array}{l}\text { Autoridad pública. } \\
\text { Persona que } \\
\text { tuviere bajo su } \\
\text { custodia a la } \\
\text { víctima. } \\
\text { Persona encargada } \\
\text { de la guarda, } \\
\text { protección o } \\
\text { vigilancia de la } \\
\text { víctima. }\end{array}$ & & \\
\hline & $\begin{array}{l}\text { Agresión sexual con } \\
\text { acceso carnal bucal, o } \\
\text { introducción de objetos } \\
\text { en vía vaginal o anal } \\
\text { ejecutada con el } \\
\text { concurso de dos o más } \\
\text { personas; o haciendo } \\
\text { uso de medios, modos o } \\
\text { instrumentos } \\
\text { especialmente brutales, } \\
\text { degradantes o } \\
\text { vejatorios; o con abuso } \\
\text { de relaciones } \\
\text { domésticas o de } \\
\text { confianza derivada de } \\
\text { relaciones de trabajo. }\end{array}$ & Cualquier persona. & Cualquier persona. & $\begin{array}{l}10 \text { años y un día a } 13 \\
\text { años y } 4 \text { meses de } \\
\text { prisión por } \\
\text { agravante del } \\
\text { Art. } 162 .\end{array}$ \\
\hline
\end{tabular}

Art. 161. Agresión sexual con o Agresión sexual sin violencia que no en menore consistiere en acceso incapaz. carnal.
Cualquier persona. Persona menor de 8 a 12 años 15 años de edad. de prisión. Persona que sufra enajenación mental.

En estado de inconsciencia. Con incapacidad de resistir.

Prole del cónyuge o 12 años y un día a 16 conviviente menor años de prisión por de 15 años de edad, agravante del o que sufra Art. 162. enajenación mental, o en estado de inconsciencia, o con incapacidad de resistir. 


\begin{tabular}{|c|c|c|c|c|}
\hline Delito & Conducta típica & Sujeto activo & Sujeto pasivo & $\begin{array}{l}\text { Consecuencia } \\
\text { jurídica }\end{array}$ \\
\hline & & $\begin{array}{l}\text { Ascendiente, } \\
\text { descendiente, } \\
\text { hermanos, } \\
\text { adoptantes, } \\
\text { adoptados. }\end{array}$ & \multirow{2}{*}{$\begin{array}{l}\text { Persona menor de } \\
15 \text { años de edad. } \\
\text { Persona que sufra } \\
\text { enajenación mental. } \\
\text { En estado de } \\
\text { inconsciencia. } \\
\text { Con incapacidad } \\
\text { de resistir. }\end{array}$} & \multirow[t]{2}{*}{$\begin{array}{l}12 \text { años y un día a } 16 \\
\text { años de prisión por } \\
\text { agravante del } \\
\text { Art. } 162 .\end{array}$} \\
\hline & & $\begin{array}{l}\text { Autoridad pública. } \\
\text { Persona que } \\
\text { tuviere bajo su } \\
\text { custodia a la } \\
\text { víctima. }\end{array}$ & & \\
\hline
\end{tabular}

\section{Persona encargada}

de la guarda,

protección o

vigilancia de la

víctima.

\begin{tabular}{|c|c|c|c|}
\hline $\begin{array}{l}\text { Agresión sexual con o } \\
\text { sin violencia que no } \\
\text { consistiere en acceso } \\
\text { carnal, ejecutada con el } \\
\text { concurso de dos o más } \\
\text { personas; o haciendo } \\
\text { uso de medios, modos o } \\
\text { instrumentos } \\
\text { especialmente brutales, } \\
\text { degradantes o } \\
\text { vejatorios; o con abuso } \\
\text { de relaciones } \\
\text { domésticas o de } \\
\text { confianza derivada de } \\
\text { relaciones de trabajo. }\end{array}$ & Cualquier persona. & $\begin{array}{l}\text { Persona menor de } \\
15 \text { años de edad. } \\
\text { Persona que sufra } \\
\text { enajenación mental. } \\
\text { En estado de } \\
\text { inconsciencia. } \\
\text { Con incapacidad } \\
\text { de resistir. }\end{array}$ & $\begin{array}{l}12 \text { años y un día a } 16 \\
\text { años de prisión por } \\
\text { agravante del } \\
\text { Art. } 162 \text {. }\end{array}$ \\
\hline \multirow[t]{2}{*}{$\begin{array}{l}\text { Si concurriere agresión } \\
\text { sexual con acceso carnal } \\
\text { bucal, o introducción de } \\
\text { objetos en vía vaginal } \\
\text { o anal. }\end{array}$} & \multirow[t]{2}{*}{ Cualquier persona. } & $\begin{array}{l}\text { Persona menor de } \\
15 \text { años de edad. } \\
\text { Persona que sufra } \\
\text { enajenación mental. } \\
\text { En estado de } \\
\text { inconsciencia. } \\
\text { Con incapacidad } \\
\text { de resistir. }\end{array}$ & $\begin{array}{l}14 \text { a } 20 \text { años de } \\
\text { prisión por } \\
\text { agravante del } \\
\text { Art. } 162 .\end{array}$ \\
\hline & & $\begin{array}{l}\text { Prole del cónyuge o } \\
\text { conviviente menor } \\
\text { de } 15 \text { años de edad, } \\
\text { o que sufra } \\
\text { enajenación mental, } \\
\text { o en estado de } \\
\text { inconsciencia, o con } \\
\text { incapacidad de } \\
\text { resistir. }\end{array}$ & $\begin{array}{l}20 \text { años y un día a } \\
26 \text { años y } 8 \text { meses } \\
\text { de prisión por } \\
\text { agravante del } \\
\text { Art. } 162 .\end{array}$ \\
\hline
\end{tabular}




$\begin{array}{llll}\text { Delito Conducta típica } \quad \text { Sujeto activo } & \text { Sujeto pasivo } & \begin{array}{l}\text { Consecuencia } \\ \text { jurídica }\end{array}\end{array}$

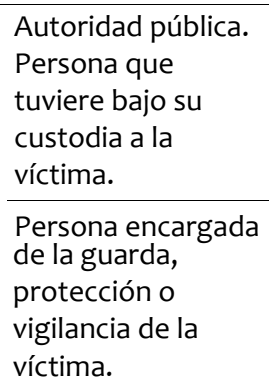

Agresión sexual con o sin violencia que no consistiere en acceso carnal, ejecutada con el concurso de dos o más personas; o haciendo uso de medios, modos o instrumentos

especialmente brutales, degradantes 0 vejatorios; o con abuso de relaciones domésticas o de confianza derivada de relaciones de trabajo.

Si concurriere agresión sexual con acceso carnal bucal, o introducción de objetos en vía vaginal $o$ anal.

\section{Cualquier persona.}

menor de 15 años de edad. años de prisión por Persona que sufra agravante del enajenación mental. Art. 162.

En estado de inconsciencia. Con incapacidad de resistir.

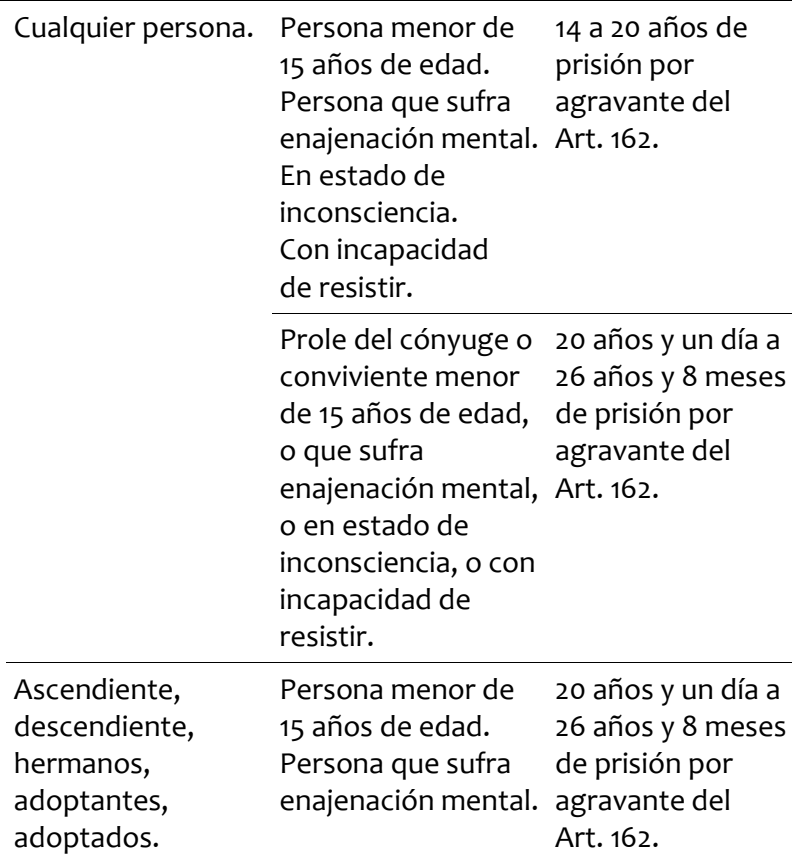




\begin{tabular}{|c|c|c|c|c|}
\hline Delito & Conducta típica & Sujeto activo & Sujeto pasivo & $\begin{array}{l}\text { Consecuencia } \\
\text { jurídica }\end{array}$ \\
\hline & & $\begin{array}{l}\text { Autoridad pública. } \\
\text { Persona que } \\
\text { tuviere bajo su } \\
\text { custodia a la } \\
\text { víctima. }\end{array}$ & \multirow[t]{2}{*}{$\begin{array}{l}\text { En estado de } \\
\text { inconsciencia. } \\
\text { Con incapacidad } \\
\text { de resistir. }\end{array}$} & \multirow[t]{2}{*}{ Art. 162.} \\
\hline & & $\begin{array}{l}\text { Persona encargada } \\
\text { de la guarda, } \\
\text { protección o } \\
\text { vigilancia de la } \\
\text { víctima. }\end{array}$ & & \\
\hline & $\begin{array}{l}\text { Agresión sexual con } \\
\text { acceso carnal bucal, o } \\
\text { introducción de objetos } \\
\text { en vía vaginal o anal } \\
\text { ejecutada con el } \\
\text { concurso de dos o más } \\
\text { personas; o haciendo } \\
\text { uso de medios, modos o } \\
\text { instrumentos } \\
\text { especialmente brutales, } \\
\text { degradantes o } \\
\text { vejatorios; o con abuso } \\
\text { de relaciones } \\
\text { domésticas o de } \\
\text { confianza derivada de } \\
\text { relaciones de trabajo. }\end{array}$ & Cualquier persona. & $\begin{array}{l}\text { Persona menor de } \\
15 \text { años de edad. } \\
\text { Persona que sufra } \\
\text { enajenación mental. } \\
\text { En estado de } \\
\text { inconsciencia. } \\
\text { Con incapacidad } \\
\text { de resistir. }\end{array}$ & $\begin{array}{l}20 \text { años y un día a } \\
26 \text { años y } 8 \text { meses } \\
\text { de prisión por } \\
\text { agravante del } \\
\text { Art. } 162 .\end{array}$ \\
\hline
\end{tabular}

Fuente: Elaboración propia a partir de Artículos contenidos en el Código Penal salvadoreño.

\section{Cuadro 4}

\section{Principales elementos de los delitos regulados en el Código Penal, Capítulo II: Del Estupro.}

\begin{tabular}{|c|c|c|c|c|}
\hline Delito & Conducta típica & Sujeto activo & Sujeto pasivo & $\begin{array}{l}\text { Consecuencia } \\
\text { jurídica }\end{array}$ \\
\hline Art. 163 Estrupo & $\begin{array}{l}\text { Acceso carnal por } \\
\text { vía vaginal o anal } \\
\text { mediante engaño. }\end{array}$ & Cualquier persona. & $\begin{array}{l}\text { Persona mayor de } 15 \\
\text { y menor de } 18 \text { años } \\
\text { de edad. }\end{array}$ & $\begin{array}{l}4 \text { años a } 10 \text { años de } \\
\text { prisión. }\end{array}$ \\
\hline $\begin{array}{l}\text { Art. } 164 \text {. Estupro por } \\
\text { prevalimiento. }\end{array}$ & $\begin{array}{l}\text { Acceso carnal por } \\
\text { vía vaginal o anal } \\
\text { prevaliéndose de } \\
\text { la superioridad } \\
\text { originada por } \\
\text { cualquier relación. }\end{array}$ & Cualquier persona. & $\begin{array}{l}\text { Persona mayor de } 15 \\
\text { y menor de } 18 \text { años } \\
\text { de edad. }\end{array}$ & $\begin{array}{l}6 \text { a } 12 \text { años de } \\
\text { prisión. }\end{array}$ \\
\hline
\end{tabular}

Fuente: Elaboración propia a partir de Artículos contenidos en el Código Penal salvadoreño. 


\section{Cuadro 5}

\section{Principales elementos de los delitos regulados en el Código Penal, Capítulo III: Otros ataques a la libertad sexual.}

\begin{tabular}{|c|c|c|c|c|}
\hline Delito & Conducta típica & Sujeto activo & Sujeto pasivo & $\begin{array}{l}\text { Consecuencia } \\
\text { jurídica }\end{array}$ \\
\hline \multirow[t]{3}{*}{ Art. 165 Acoso sexual. } & \multirow[b]{2}{*}{$\begin{array}{l}\text { Realizar conducta } \\
\text { sexual indeseada } \\
\text { por quien la recibe, } \\
\text { que implique frases, } \\
\text { tocamiento, señas u } \\
\text { otra conducta } \\
\text { inequívoca de } \\
\text { naturaleza o } \\
\text { contenido sexual. }\end{array}$} & \multirow[t]{2}{*}{ Cualquier persona. } & Cualquier persona. & 3 a 5 años de prisión. \\
\hline & & & $\begin{array}{l}\text { Persona menor de } \\
15 \text { años de edad. }\end{array}$ & $\begin{array}{l}4 \text { a } 8 \text { años } \\
\text { de prisión. }\end{array}$ \\
\hline & $\begin{array}{l}\text { Si el acoso se } \\
\text { realizare } \\
\text { prevaliéndose de la } \\
\text { superioridad } \\
\text { originada por } \\
\text { cualquier relación. }\end{array}$ & Cualquier persona. & Cualquier persona. & $\begin{array}{l}\text { A la pena de prisión } \\
\text { se añadirá multa de } \\
100 \text { a } 200 \text { días multa. } \\
\text { (Día multa puede } \\
\text { variar entre } \$ 44.77 \text { - } \\
\$ 568.50 \text { ) }\end{array}$ \\
\hline \multirow[t]{2}{*}{$\begin{array}{l}\text { Art. } 166 \text { Acto sexual } \\
\text { diverso. }\end{array}$} & \multirow{2}{*}{$\begin{array}{l}\text { Realizar mediante } \\
\text { engaño cualquier } \\
\text { acto sexual diverso } \\
\text { del acceso carnal. }\end{array}$} & \multirow[t]{2}{*}{ Cualquier persona. } & $\begin{array}{l}\text { Persona mayor de } \\
15 \text { y menor de } 18 \\
\text { años de edad. }\end{array}$ & $\begin{array}{l}4 \text { a } 8 \text { años } \\
\text { de prisión. }\end{array}$ \\
\hline & & & $\begin{array}{l}\text { Persona menor de } \\
16 \text { años de edad, } \\
\text { aún con su } \\
\text { consentimiento. }\end{array}$ & $\begin{array}{l}8 \text { a } 12 \text { años } \\
\text { de prisión. }\end{array}$ \\
\hline \multirow[t]{2}{*}{$\begin{array}{l}\text { Art. } 167 \text { Corrupción } \\
\text { de menores e } \\
\text { incapaces. }\end{array}$} & $\begin{array}{l}\text { Promover o facilitar } \\
\text { la corrupción } \\
\text { mediante actos } \\
\text { sexuales diversos } \\
\text { del acceso carnal, } \\
\text { aun con el } \\
\text { consentimiento de } \\
\text { la víctima. }\end{array}$ & Cualquier persona. & $\begin{array}{l}\text { Persona con edad a } \\
\text { partir de los } 15 \text { años } \\
\text { y menor a los } 18 \\
\text { años de edad o } \\
\text { deficiente mental. }\end{array}$ & $\begin{array}{l}6 \text { a } 12 \text { años } \\
\text { de prisión. }\end{array}$ \\
\hline & $\begin{array}{l}\text { Favorecer la } \\
\text { corrupción de } \\
\text { menores o } \\
\text { incapaces. }\end{array}$ & Cualquier persona. & $\begin{array}{l}\text { Persona con edad a } \\
\text { partir de los } 15 \text { años } \\
\text { y menor a los } 18 \\
\text { años de edad o } \\
\text { deficiente mental. }\end{array}$ & $\begin{array}{l}12 \text { años un día a } 16 \\
\text { años de prisión. }\end{array}$ \\
\hline $\begin{array}{l}\text { Art. } 168 \text { Corrupción } \\
\text { agravada. }\end{array}$ & $\begin{array}{l}\text { Promover o facilitar } \\
\text { la corrupción } \\
\text { mediante actos } \\
\text { sexuales diversos } \\
\text { del acceso carnal. }\end{array}$ & Cualquier persona. & $\begin{array}{l}\text { Persona menor de } \\
15 \text { años de edad. }\end{array}$ & $\begin{array}{l}12 \text { a } 14 \text { años } \\
\text { de prisión. }\end{array}$ \\
\hline
\end{tabular}




\begin{tabular}{|c|c|c|c|c|}
\hline Delito & Conducta típica & Sujeto activo & Sujeto pasivo & $\begin{array}{l}\text { Consecuencia } \\
\text { jurídica }\end{array}$ \\
\hline & & & $\begin{array}{l}\text { Persona menor de } \\
18 \text { años prole del } \\
\text { cónyuge o } \\
\text { conviviente. }\end{array}$ & \\
\hline & & $\begin{array}{l}\text { Ascendiente, } \\
\text { adoptante, } \\
\text { hermano, } \\
\text { encargado de la } \\
\text { educación, } \\
\text { vigilancia, cuidado o } \\
\text { guarda de víctima. }\end{array}$ & $\begin{array}{l}\text { Persona menor de } \\
18 \text { años de edad o } \\
\text { deficiente mental. }\end{array}$ & \\
\hline & $\begin{array}{l}\text { Promover o facilitar } \\
\text { la corrupción } \\
\text { mediante actos } \\
\text { sexuales diversos } \\
\text { del acceso carnal } \\
\text { mediante engaño, } \\
\text { violencia, abuso de } \\
\text { autoridad o } \\
\text { confianza, o por } \\
\text { cualquier otro } \\
\text { medio de } \\
\text { intimidación. }\end{array}$ & Cualquier persona. & $\begin{array}{l}\text { Persona menor de } \\
18 \text { años de edad o } \\
\text { deficiente mental. }\end{array}$ & $\begin{array}{l}12 \text { a } 14 \text { años } \\
\text { de prisión. }\end{array}$ \\
\hline
\end{tabular}

Art. 169 Inducción, promoción y favorecimiento de actos sexuales o eróticos.
Promover, facilitar, administrar, financiar, instigar $u$ organizar cualquier forma de utilización de personas en actos sexuales 0 eróticos, de manera individual u organizada, de forma pública o privada.

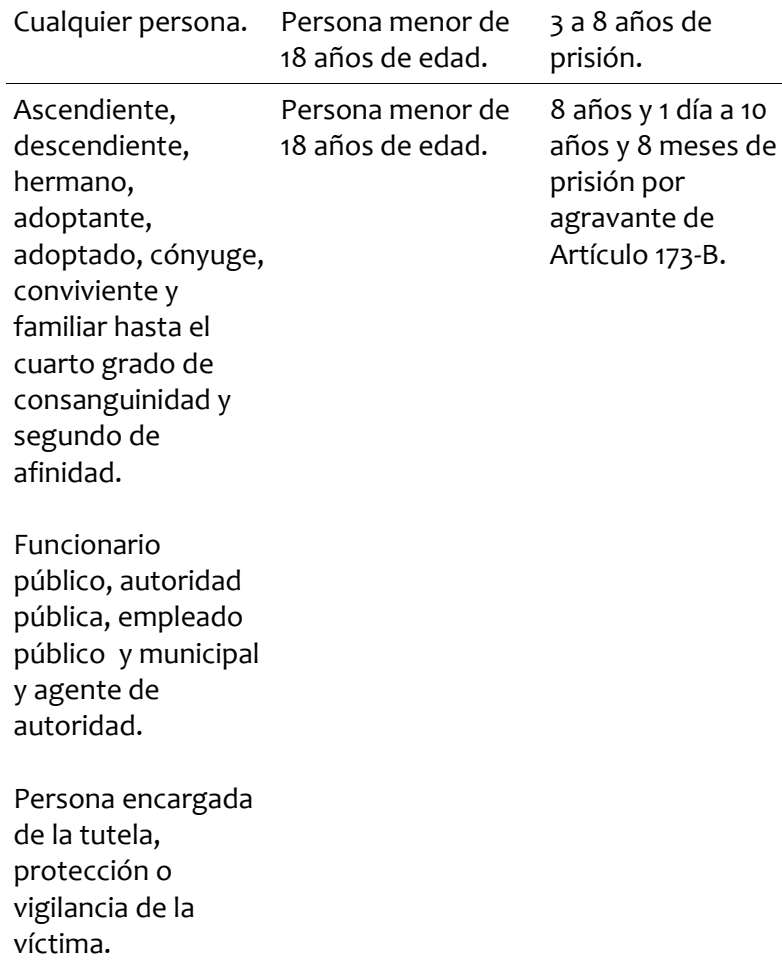
18 años de edad. prisión.

Ascendiente, Persona menor de 8 años y 1 día a 10 descendiente, 18 años de edad. años y 8 meses de hermano, adoptante, adoptado, cónyuge, prisión por agravante de conviviente y familiar hasta el cuarto grado de consanguinidad y segundo de afinidad.

Funcionario público, autoridad pública, empleado público y municipal $y$ agente de autoridad.

Persona encargada de la tutela, protección o vigilancia de la víctima. 


\begin{tabular}{|c|c|c|c|c|}
\hline Delito & Conducta típica & Sujeto activo & Sujeto pasivo & $\begin{array}{l}\text { Consecuencia } \\
\text { jurídica }\end{array}$ \\
\hline & $\begin{array}{l}\text { Realizar la conducta } \\
\text { típica prevaliéndose } \\
\text { de la superioridad } \\
\text { originada por } \\
\text { relaciones de } \\
\text { confianza, } \\
\text { doméstica, } \\
\text { educativa, de } \\
\text { trabajo o cualquier } \\
\text { otra relación. }\end{array}$ & Cualquier persona. & $\begin{array}{l}\text { Persona menor de } \\
18 \text { años de edad. }\end{array}$ & $\begin{array}{l}8 \text { años y } 1 \text { día a } 10 \\
\text { años y } 8 \text { meses de } \\
\text { prisión por } \\
\text { agravante de } \\
\text { Artículo 173-B. }\end{array}$ \\
\hline & $\begin{array}{l}\text { Autorizar el uso o } \\
\text { arrendar el } \\
\text { inmueble para } \\
\text { realizar las } \\
\text { conductas de } \\
\text { inducción, } \\
\text { promoción y } \\
\text { favorecimiento de } \\
\text { actos sexuales o } \\
\text { eróticos. }\end{array}$ & Cualquier persona. & $\begin{array}{l}\text { Personas menores } \\
\text { de } 18 \text { años de edad. }\end{array}$ & $\begin{array}{l}3 \text { a } 8 \text { años de } \\
\text { prisión. }\end{array}$ \\
\hline $\begin{array}{l}\text { Art. 169-A } \\
\text { Remuneración por } \\
\text { actos sexuales o } \\
\text { eróticos. }\end{array}$ & $\begin{array}{l}\text { Pagar o prometer } \\
\text { pagar con dinero u } \\
\text { otra ventaja de } \\
\text { cualquier naturaleza } \\
\text { a persona menor de } \\
18 \text { años o a una } \\
\text { tercera persona } \\
\text { para que la persona } \\
\text { menor de edad } \\
\text { ejecute actos } \\
\text { sexuales o eróticos. }\end{array}$ & Cualquier persona. & $\begin{array}{l}\text { Persona menor de } \\
18 \text { años de edad. }\end{array}$ & $\begin{array}{l}3 \text { a } 8 \text { años de } \\
\text { prisión. }\end{array}$ \\
\hline \multirow{4}{*}{$\begin{array}{l}\text { Art. } 170 \\
\text { Determinación a la } \\
\text { prostitución. }\end{array}$} & \multirow{2}{*}{$\begin{array}{l}\text { Determinar, } \\
\text { coactivamente o } \\
\text { abusando de una } \\
\text { situación de } \\
\text { necesidad a una } \\
\text { persona para que } \\
\text { ejerciere la } \\
\text { prostitución o se } \\
\text { mantuviere en ella. }\end{array}$} & Cualquier persona. & Cualquier persona. & $\begin{array}{l}6 \text { a } 10 \text { años } \\
\text { de prisión. }\end{array}$ \\
\hline & & Cualquier persona. & $\begin{array}{l}\text { Persona menor de } \\
18 \text { años de edad. }\end{array}$ & $\begin{array}{l}8 \text { a } 12 \text { años } \\
\text { de prisión. }\end{array}$ \\
\hline & \multirow{2}{*}{$\begin{array}{l}\text { Ejecutar la conducta } \\
\text { Prevaliéndose de la } \\
\text { superioridad } \\
\text { originada por } \\
\text { cualquier relación. }\end{array}$} & Cualquier persona. & Cualquier persona. & $\begin{array}{l}10 \text { años y } 1 \text { día a } 13 \\
\text { años y } 4 \text { meses } \\
\text { de prisión. }\end{array}$ \\
\hline & & Cualquier persona. & $\begin{array}{l}\text { Persona menor de } \\
18 \text { años de edad. }\end{array}$ & $\begin{array}{l}12 \text { años y } 1 \text { día a } 16 \\
\text { años de prisión. }\end{array}$ \\
\hline $\begin{array}{l}\text { Art. 170-A. } \\
\text { Oferta y demanda de } \\
\text { prostitución ajena. }\end{array}$ & $\begin{array}{l}\text { Ofertar u ofrecer } \\
\text { servicios de } \\
\text { prostitución ajena. }\end{array}$ & Cualquier persona. & Cualquier persona. & $\begin{array}{l}4 \text { a } 8 \text { años de } \\
\text { prisión. }\end{array}$ \\
\hline
\end{tabular}




\begin{tabular}{|c|c|c|c|c|}
\hline Delito & Conducta típica & Sujeto activo & Sujeto pasivo & $\begin{array}{l}\text { Consecuencia } \\
\text { jurídica }\end{array}$ \\
\hline & $\begin{array}{l}\text { Demandar o } \\
\text { solicitar servicios de } \\
\text { prostitución. }\end{array}$ & & & \\
\hline $\begin{array}{l}\text { Art. 171. Exhibiciones } \\
\text { Obscenas. }\end{array}$ & $\begin{array}{l}\text { El que ejecutare o } \\
\text { hiciere ejecutar a } \\
\text { otros actos lúbricos } \\
\text { o de exhibición } \\
\text { obscena, o } \\
\text { indecorosa, en lugar } \\
\text { público o expuesto } \\
\text { al público o ante } \\
\text { menores de } 18 \text { años } \\
\text { de edad o } \\
\text { deficientes } \\
\text { mentales. }\end{array}$ & Cualquier persona. & Cualquier persona. & 2 a 4 años de prisión. \\
\hline
\end{tabular}

Art. 172 Pornografía. Fabricar, transferir, Cualquier persona. Persona menor de 3 a 5 años de prisión. difundir, distribuir, 18 años de edad. alquilar, vender, ofrecer, producir, ejecutar, exhibir o Deficientes mostrar películas, mentales. revistas, pasquines o cualquier otro material pornográfico.

No advertir de forma visible sobre el contenido de las películas, revistas, pasquines 0 cualquier material cuando este fuere inadecuado para menores de 18 años o deficientes mentales.

Art. 173 Utilización de personas menores de 18 años e incapaces o deficientes mentales en pornografía.
Producir, reproducir, distribuir, publicar, importar, exportar, ofrecer, financiar, vender, comerciar o difundir de cualquier forma imágenes, utilizar la voz se en forma

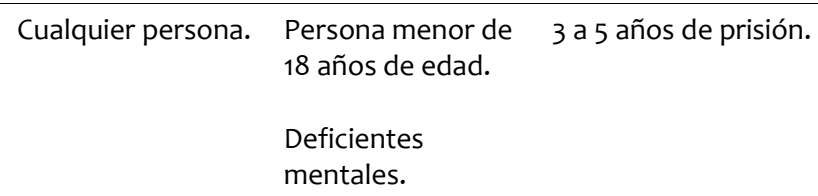
18 años de edad.

Deficientes mentales. . 


\begin{tabular}{|c|c|c|c|c|}
\hline Delito & Conducta típica & Sujeto activo & Sujeto pasivo & $\begin{array}{l}\text { Consecuencia } \\
\text { jurídica }\end{array}$ \\
\hline & $\begin{array}{l}\text { directa, informática, } \\
\text { audiovisual, virtual o } \\
\text { por cualquier otro } \\
\text { medio en el que } \\
\text { exhiban, en } \\
\text { actividades } \\
\text { sexuales, eróticas o } \\
\text { inequívocas de } \\
\text { naturaleza sexual, } \\
\text { explícitas o no, } \\
\text { reales o simuladas. }\end{array}$ & $\begin{array}{l}\text { adoptado, cónyuge, } \\
\text { conviviente y } \\
\text { familiar hasta el } \\
\text { cuarto grado de } \\
\text { consanguinidad y } \\
\text { segundo de } \\
\text { afinidad. } \\
\text { Funcionario } \\
\text { público, autoridad } \\
\text { pública, empleado } \\
\text { público y municipal } \\
\text { y agente de } \\
\text { autoridad. } \\
\text { Persona encargada } \\
\text { de la tutela, } \\
\text { protección o } \\
\text { vigilancia de la } \\
\text { víctima. }\end{array}$ & Deficiente mental. & \\
\hline & $\begin{array}{l}\text { Realizar la conducta } \\
\text { típica prevaliéndose } \\
\text { de la superioridad } \\
\text { originada por } \\
\text { relaciones de } \\
\text { confianza, } \\
\text { doméstica, } \\
\text { educativa, de } \\
\text { trabajo o cualquier } \\
\text { otra relación. }\end{array}$ & Cualquier persona. & $\begin{array}{l}\text { Persona menor de } \\
18 \text { años. } \\
\text { Incapaz. } \\
\text { Deficiente mental. }\end{array}$ & $\begin{array}{l}12 \text { años y un día a } 16 \\
\text { años de prisión por } \\
\text { agravante de } \\
\text { Art. } 173-B .\end{array}$ \\
\hline & $\begin{array}{l}\text { Organizar o } \\
\text { participar en } \\
\text { espectáculos, } \\
\text { públicos o privados, } \\
\text { en los que se hace } \\
\text { participar a los } \\
\text { sujetos pasivos, en } \\
\text { acciones } \\
\text { pornográficas o } \\
\text { eróticas. }\end{array}$ & Cualquier persona. & $\begin{array}{l}\text { Persona menor de } \\
18 \text { años. } \\
\text { Incapaz. } \\
\text { Deficiente mental. }\end{array}$ & $\begin{array}{l}6 \text { a } 12 \text { años de } \\
\text { prisión. }\end{array}$ \\
\hline $\begin{array}{l}\text { Art. 173-A. Posesión } \\
\text { de pornografía. }\end{array}$ & $\begin{array}{l}\text { Poseer material } \\
\text { pornográfico en el } \\
\text { que se utilice la } \\
\text { imagen del sujeto } \\
\text { pasivo en } \\
\text { actividades } \\
\text { pornográficas o } \\
\text { eróticas. }\end{array}$ & Cualquier persona. & $\begin{array}{l}\text { Persona menor de } \\
18 \text { años de edad. } \\
\text { Incapaz. } \\
\text { Deficientes } \\
\text { mentales. }\end{array}$ & 2 a 4 años. \\
\hline
\end{tabular}

Fuente: Elaboración propia a partir de Artículos contenidos en el Código Penal salvadoreño. 


\section{Cuadro 6}

\section{Delitos regulados en la LEIV, Capítulo I: Delitos y sanciones; vinculados con la libertad sexual.}

\begin{tabular}{|c|c|c|c|c|}
\hline Delito & Conducta típica & Sujeto activo & Sujeto pasivo & $\begin{array}{l}\text { Consecuencia } \\
\text { jurídica }\end{array}$ \\
\hline \multirow[t]{6}{*}{$\begin{array}{l}\text { Art. } 45 \\
\text { letra d) Feminicidio. }\end{array}$} & $\begin{array}{l}\text { Causar la muerte a } \\
\text { una mujer } \\
\text { mediando motivos } \\
\text { de odio o } \\
\text { menosprecio por su } \\
\text { condición de mujer: } \\
\text { que previo a su } \\
\text { muerte el autor } \\
\text { hubiere cometido } \\
\text { contra ella cualquier } \\
\text { conducta calificada } \\
\text { como delito contra } \\
\text { la libertad sexual. }\end{array}$ & Cualquier persona. & $\begin{array}{l}\text { Persona del sexo } \\
\text { femenino. }\end{array}$ & $\begin{array}{l}20 \text { a } 35 \text { años } \\
\text { de prisión. }\end{array}$ \\
\hline & $\begin{array}{l}\text { Realizar la conducta } \\
\text { típica por dos o más } \\
\text { personas. }\end{array}$ & & & $\begin{array}{l}30 \text { a } 35 \text { años de } \\
\text { prisión por } \\
\text { agravante del } \\
\text { Art. } 46 .\end{array}$ \\
\hline & $\begin{array}{l}\text { Realizar la conducta } \\
\text { típica frente a } \\
\text { cualquier familiar de } \\
\text { la víctima. }\end{array}$ & & & \\
\hline & $\begin{array}{l}\text { Realizar la conducta } \\
\text { típica prevaliéndose } \\
\text { de la superioridad } \\
\text { originada por } \\
\text { relaciones de } \\
\text { confianza, amistad, } \\
\text { doméstica, } \\
\text { educativa o de } \\
\text { trabajo. }\end{array}$ & & & \\
\hline & \multirow{2}{*}{$\begin{array}{l}\text { Causar la muerte a } \\
\text { una mujer } \\
\text { mediando motivos } \\
\text { de odio o } \\
\text { menosprecio por su } \\
\text { condición de mujer: } \\
\text { que previo a su } \\
\text { muerte el autor }\end{array}$} & $\begin{array}{l}\text { Funcionario o } \\
\text { empleado público } \\
\text { o municipal, } \\
\text { autoridad pública } \\
\text { o agente de } \\
\text { autoridad. }\end{array}$ & $\begin{array}{l}\text { Persona del sexo } \\
\text { femenino. }\end{array}$ & $\begin{array}{l}30 \text { a } 35 \text { años de } \\
\text { prisión por } \\
\text { agravante del } \\
\text { Art. } 46 .\end{array}$ \\
\hline & & Cualquier persona. & $\begin{array}{l}\text { Persona menor de } \\
18 \text { años de edad del } \\
\text { sexo femenino. }\end{array}$ & $\begin{array}{l}30 \text { a } 35 \text { años de } \\
\text { prisión por } \\
\text { agravante del } \\
\text { Art. } 46 .\end{array}$ \\
\hline Instituto de Ciencia, TeCNOL & ogía E lnNNOVACIÓN (ICTI) & & & \\
\hline
\end{tabular}




\begin{tabular}{|c|c|c|c|c|}
\hline Delito & Conducta típica & Sujeto activo & Sujeto pasivo & $\begin{array}{l}\text { Consecuencia } \\
\text { jurídica }\end{array}$ \\
\hline & $\begin{array}{l}\text { hubiere cometido } \\
\text { contra ella cualquier } \\
\text { conducta calificada } \\
\text { como delito contra } \\
\text { la libertad sexual. }\end{array}$ & & $\begin{array}{l}\text { Persona adulta } \\
\text { mayor del sexo } \\
\text { femenino (a partir } \\
\text { de } 60 \text { años de } \\
\text { edad). } \\
\text { Persona que } \\
\text { sufriere } \\
\text { discapacidad física } \\
\text { o mental del sexo } \\
\text { femenino. }\end{array}$ & \\
\hline $\begin{array}{l}\text { Art. } 49 \text { Inducción, } \\
\text { promoción y } \\
\text { favorecimiento de } \\
\text { actos sexuales o } \\
\text { eróticos por medios } \\
\text { informáticos o } \\
\text { electrónicos. }\end{array}$ & $\begin{array}{l}\text { De manera } \\
\text { individual, colectiva } \\
\text { u organizada } \\
\text { publicar, distribuir, } \\
\text { enviar, promover, } \\
\text { facilitar, } \\
\text { administrar, } \\
\text { financiar u } \\
\text { organizar, de } \\
\text { cualquier forma la } \\
\text { utilización de } \\
\text { mujeres sin su } \\
\text { consentimiento en } \\
\text { actos sexuales o } \\
\text { eróticos, utilizando } \\
\text { medios } \\
\text { informáticos. }\end{array}$ & Cualquier persona. & $\begin{array}{l}\text { Persona mayor de } \\
18 \text { años del sexo } \\
\text { femenino. }\end{array}$ & $\begin{array}{l}5 \text { a } 10 \text { años } \\
\text { de prisión. }\end{array}$ \\
\hline $\begin{array}{l}\text { Art. } 51 \text { Difusión } \\
\text { de pornografía. }\end{array}$ & $\begin{array}{l}\text { Publicar, compartir, } \\
\text { enviar o distribuir } \\
\text { material } \\
\text { pornográfico por } \\
\text { cualquier medio } \\
\text { informático o } \\
\text { electrónico en el } \\
\text { que se utilice la } \\
\text { imagen o identidad } \\
\text { de la mujer sin su } \\
\text { consentimiento. }\end{array}$ & Cualquier persona. & $\begin{array}{l}\text { Persona mayor de } \\
18 \text { años del sexo } \\
\text { femenino. }\end{array}$ & $\begin{array}{l}3 \text { a } 5 \text { años } \\
\text { de prisión. }\end{array}$ \\
\hline
\end{tabular}

Fuente: Elaboración propia a partir de Artículos contenidos en el Código Penal salvadoreño. 


\section{Conclusiones}

Tras el análisis de los tipos penales que protegen la libertad sexual en la legislación penal salvadoreña, podemos apuntar las siguientes conclusiones. En primer lugar, consideramos que estos delitos no solo protegen el bien jurídico libertad sexual, sino que también algunos de estos tipos penales protegen el bien jurídico indemnidad sexual; sobre todo, aquellos que sancionan la vulneración de la esfera sexual de niños, niñas o adolescentes. En este sentido, recomendamos que se modifique el nombre del Título IV a "Delitos contra la Libertad e Indemnidad Sexual".

En segundo lugar, consideramos que equiparar al delito de agresión sexual cometido mediante acceso carnal bucal, o por introducción de objetos en vía vaginal o anal, con el delito de violación, refuerza la creencia de que la conducta más grave de violencia sexual lo constituye el acceso carnal. En este sentido, consideremos que la legislación penal salvadoreña debe dar más énfasis a la vulneración del bien jurídico protegido en la víctima, y no a la forma en que se comete la acción, sobre todo, para no reforzar estereotipos de género sobre el papel de sujeto pasivo y receptor de la mujer en una relación sexual.

En tercer lugar, ha quedado evidenciado que los rangos de edades establecidos para el consentimiento sexual no son de igual categoría para todos los delitos regulados en el Título de delitos contra la libertad sexual. Así, en alguno tipos, por ejemplo el estupro, se infiere que pueden consentir a tener acceso carnal las personas mayores de 15 años, mientras que en el delito de acto sexual diverso pareciera que con la fórmula "mayor de quince años" el legislador se refiere a las personas que tengan 16 años o más, y no 15 años, como podríamos interpretar en el delito de estupro. La falta de coordinación entre las edades establecidas en estos tipos penales puede generar confusiones que, dadas las garantías establecidas en el derecho penal, deberán interpretarse restrictivamente en favor del reo.

En cuarto lugar, resulta cuestionable que el legislador penal salvadoreño haya dejado por fuera la sanción de las conductas de publicar, distribuir, enviar, promover, facilitar, administrar, financiar u organizar, de cualquier forma la utilización de personas del sexo masculino sin su consentimiento en actos sexuales o eróticos; al igual que las acciones de publicar, compartir, enviar o distribuir material pornográfico de este grupo de personas, puesto que estos también pueden ser víctimas de este tipo de delitos, sobre todo, aquellos cuya identidad de género esté asociada con el género femenino, y por tanto, sufren en similar medida los estereotipos y discriminaciones dados a las mujeres.

Finalmente, en cuanto a la exclusiva mención de los Capítulos I y II del Título IV en el Artículo 174, que establece las indemnizaciones especiales, no se comprende por qué el legislador consideró dejar fuera de esta disposición a todos los Artículos regulados en el Capítulo III, el cual contiene el mayor número de delitos, muchos de ellos relacionados con la explotación sexual comercial, principalmente en personas menores de edad. Si bien esta omisión queda solventada con la disposición general que hace el legislador penal en el Título VI: Consecuencias civiles del hecho punible 
(Arts. 114-125), sugerimos la modificación de este Artículo para que se comprenda en el mismo al Capítulo III del Título IV del Código Penal, lo cual estaría en consonancia con el espíritu del legislador en cuanto a la protección integral de la libertad e indemnidad sexual de todas las

\section{Referencias}

1 OMS (2003), p. 161.

2 Convención Interamericana para Prevenir, Sancionar y Erradicar la Violencia contra la Mujer (1994).

$3 \operatorname{UNFPA}(2011)$, p. 22.

4 CONTRERAS; BOTT; GUEDES; DARTNALL (2010), pp. 7-8.

5 UNFPA (2011), pp. 3 y 15.

6 OIT (2003), pp. 55-56.

7 No obstante, Estados Unidos, Canadá y Cuba todavía no han ratificado o tomado pasos para ratificar la Convención de Belém do Pará; mientras que Chile, Cuba, El Salvador y Estados Unidos no han ratificado el Protocolo Facultativo de la CEDAW. Cfr. OEA (2007), p. 97.

8 OEA (2007), pp. 9, 110 y 112.

9 CONTRERAS; BOTT; GUEDES; DARTNALL (2010), p. 9.

10 UNFPA (2011), p. 28. Asimismo, en el caso de El Salvador, se ha señalado que en la gran mayoría de las investigaciones de delitos sexuales no se aplican métodos personas. Asimismo, se hace necesario dar un enfoque restaurativo de derechos a las indemnizaciones establecidas en dicho Artículo.

Artículo recibido: 26 de mayo de 2014 Artículo aprobado: 7 de julio 2014

científicos y existe una carencia notable de protocolos y metodologías para la investigación de estos delitos, lo que evidencia la necesidad de que los aplicadores del derecho interpreten los tratados internacionales de derechos humanos en concordancia con los estándares internacionales. Cfr. OEA (2007), pp. 58 y 97.

11 OEA (2007), pp. 1 y ss.

12 UNFPA (2010), 19.

13 UNFPA (2010), p. 20.

16 LÓPEZ ORTIZ; PEÑA; PERLA LÓPEZ (2012), p. 21.

18 UNFPA (2010), p. 20.

19 ORMUSA (2014).

20 ADS (2009), pp. 245-246.

21 ORMUSA.

22 OIT (2003), p. 55.

23 ADS (2009), p. 245.

24 ORMUSA (2014). 
25 Fiscalía General de la República.

26 Instituto Salvadoreño para el Desarrollo de la Mujer.

27 UNFPA (2010), pp. 34-35.

28 UNFPA (2010), pp. 34-35.

29 OIT (2003), p. 55.

30 Artículo 144 de la Constitución de El Salvador.

31 Art. 1 Ley contra la Violencia Intrafamiliar.

32 Art. 3 letra c) Ley contra la Violencia Intrafamiliar.

33 Art. 14 Ley contra la Violencia Intrafamiliar

34 Art. 21 Ley contra la Violencia Intrafamiliar

35 Art. 4 Ley contra la Violencia Intrafamiliar

36 Exposición de Motivos. Ley Especial Integral para una Vida Libre de Violencia para las Mujeres.

37 Art. 37 LEPINA.

38 Art. 38 LEPINA.

39 Art. 41 LEPINA.

40 Este Código Penal se encuentra vigente desde el 20 de abril de 1998. A finales del año 2003 se llevó a cabo una importante reforma que introdujo al Código Penal tipos penales aplicables a la explotación sexual comercial de personas menores de edad, tales como la remuneración por actos sexuales eróticos, oferta y demanda de prostitución ajena y posesión de pornografía. Cfr. UNFPA (2010), p. 20.

41 MORENO CARRASCO-RUEDA GARCÍA (2004a), p. 596.

42 Ver DÍEZ RIPOLLÉS (1985) y MORENO CARRASCO-RUEDA GARCÍA (2004a), p. 596.

43 BOLDOVA PASAMAR (2004).

44 MUÑOZ CONDE (1996).

45 SUÁREZ (1995).

46 ABOSO-ZAPATA (2006).

47 Esta ha sido la postura mayoritariamente adoptada en la jurisprudencia salvadoreña, Ver por todas: STS 0302-117-2005, STS 0103-70-2004, STS 0302-72-2004, STS 130110-2006 / 9-2-2006. Cfr. Bolaños VásquezBoldova Pasamar-Fuertes. Iglesias (2014), pp. 94-98

48 STS 1301-19-2003; STS 1301-86-2004.

49 Cfr. ABOSO-ZAPATA (2006); PARMA (1999); RINCÓN-NARANJO (2012).

50 Esto podría explicarse en el hecho de que anteriormente -tal como explicábamos supra- el orden moral diferenciaba los vasos "debidos" e "indebidos", entendiéndose por vasos indebidos aquellos distintos de la vagina, a saber, el ano y la boca, por servir de "remedo" de los genitales en tanto permiten una especie de cópula. Cfr. Parrini (2013), p. 70.

51 Otros delitos regulados en el Código Penal salvadoreño que tienen la misma pena que 
la violación (seis a diez años de prisión) son robo (Art. 212), contaminación ambiental agravada (Art. 256), comercio y transporte de sustancias peligrosas (Art. 262-B) y cohecho activo (Art. 335).

52 UNFPA (2010), p. 20.
53 UNFPA (2010), p. 25.

54 UNFPA (2010), p. 27.

55 MORENO CARRASCO-RUEDA GARCÍA (2004b), p. 641.

56 UNFPA (2010), pp. 21 y 22. 